
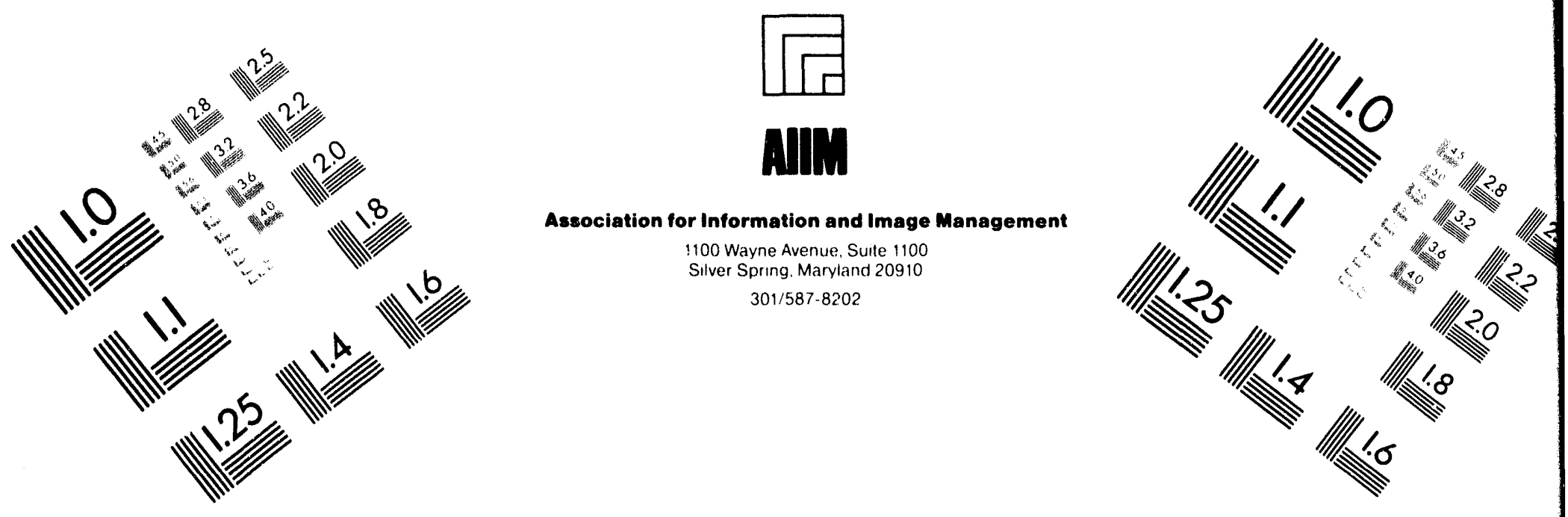

Centimeter

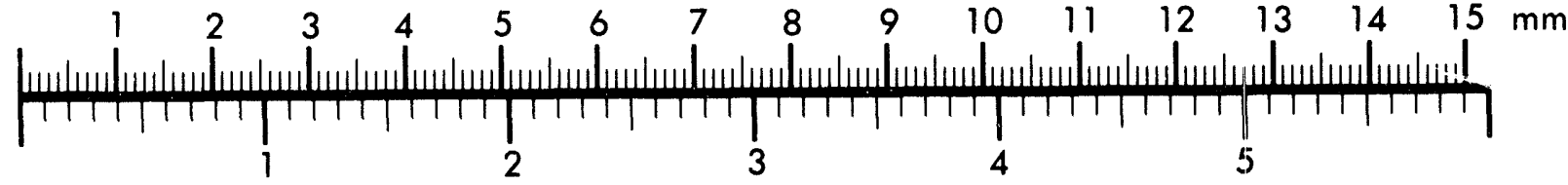

Inches
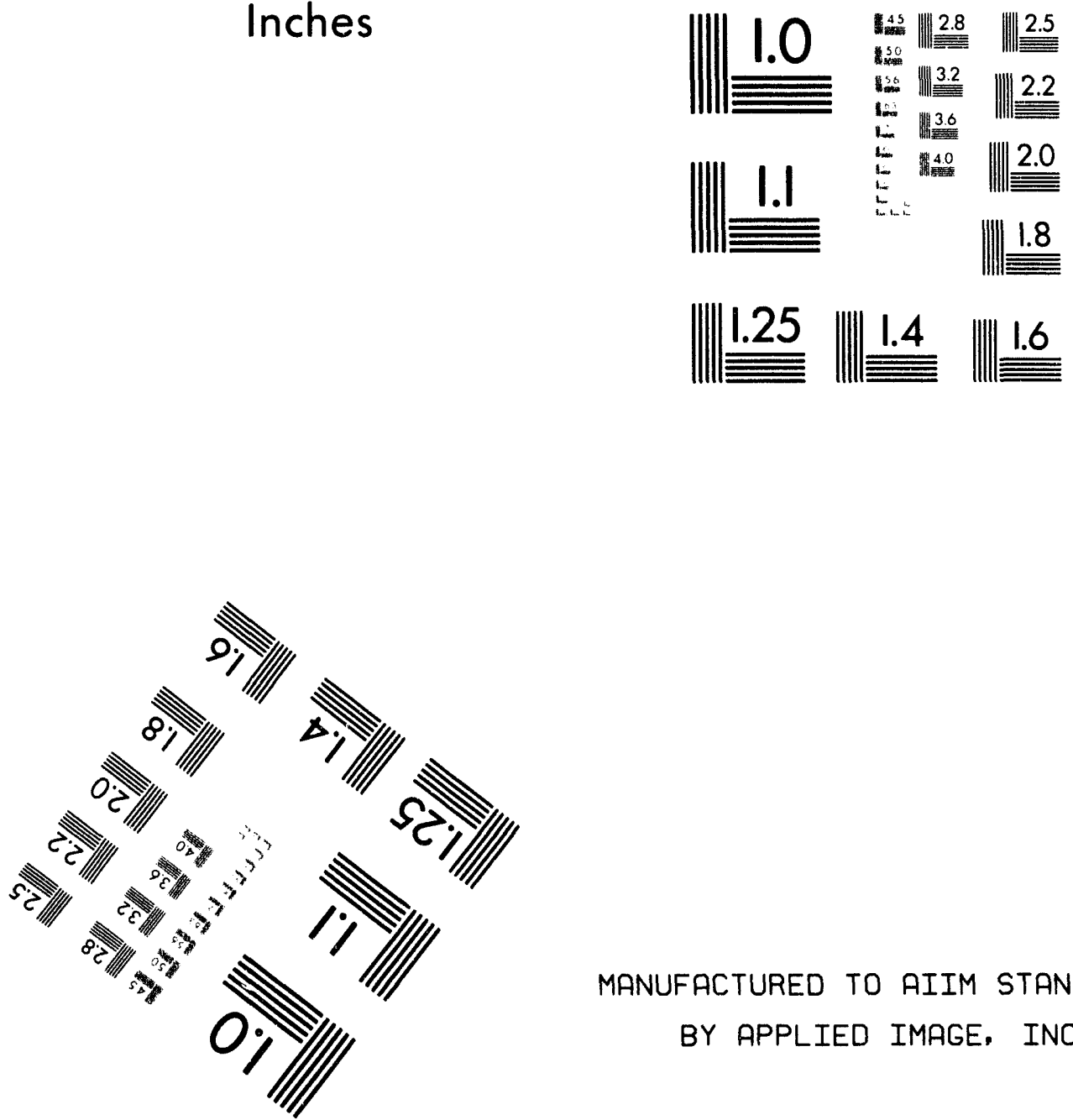

MANUFACTURED TO AIIM STANDARDS

BY APPLIED IMAGE, INC.

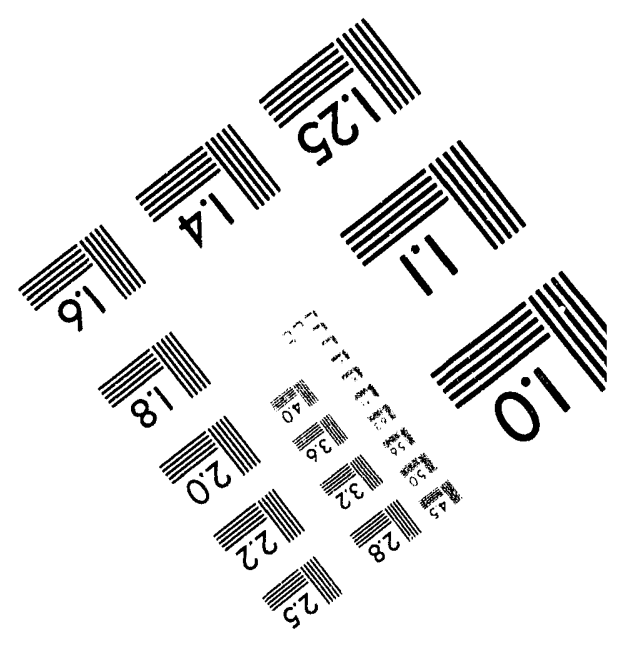



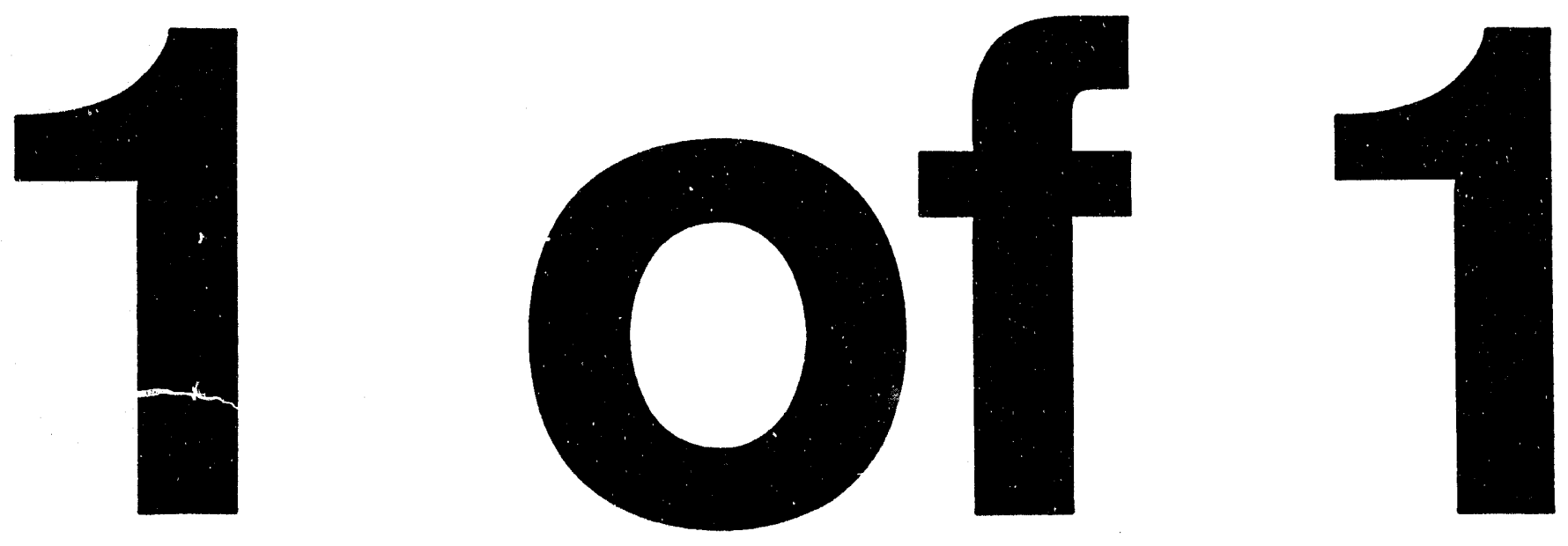


\section{Report to the United States Congress}

\section{Clean Coal Technology Export Markets and Financing Mechanisms}

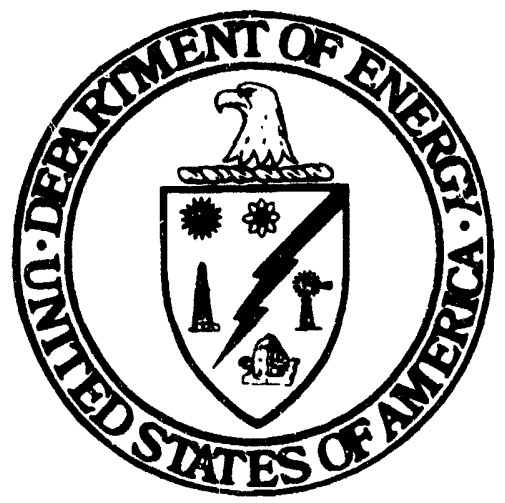

May 1994

United States Department of Energy Assistant Secretary for Fossil Energy Washington, DC 20585 
TABLE OF CONTENTS

Page

EXECUTIVE SUMMARY

Markets for Clean Coal Technologies

S-1

Financing Mechanisms for Clean Coal Technologies

S-3

Implementation of International Coal Technology Transfer

S-4

1. INTRODUCTION

Significance of Clean Coal Technology Exports

$1-1$

Relevant Energy Policy Act Provision

Related Initiatives

1-3

Clean Coal Technologies for Developing and Transitional Countries

$1-4$

Benefits for the U.S. and its Foreign Partners

$1-4$

Related Reports

2. MARKETS FOR CLEAN COAL TECHNOLOGIES

Asia-Pacific Region

Transitional Economies

Other Regions

2-24

Technology Selection

3. FINANCING MECHANISMS FOR CLEAN COAL TECHNOLOGY PROJECTS

Financing of Preliminary Project Development Activities

Financing of Project Construction

Levels of Support Potentially Necessary

Implications

4. IMPLEMENTATION OF INTERNATIONAL CLEAN COAL TECHNOLOGY TRANSFER

Planned Approach to Technology Transfer 


\section{TABLES}

Page

Table 2-1 Potential CCT Markets Outside the United States (1993-2010) 2-3

Table 3-1 Prefeasibility/Feasibility Studies and Project Finance: Multi?ateral Development 3-6 Banks

Table 3-2 Financial Assistance Offered by Federal Agencies

Table 3-3 Potential Annual U.S. Government Financing of International CCT Projects 


\section{EXECUTTVE SUMMARY}

This report responds to a Congressional Conference Report ${ }^{1}$ that requests:

That \$625,000 in coal technology export is for initial implementation of section 1332 of the Energy Policy Act of 1992. The managers expect that the funding provided will be used by the Department to identify potential markets for clean coal technologies in developing countries and countries with economies in transition from nonmarket economies and to identify existing, or new, financial mechanisms or financial support to be provided by the Federal government that will enhance the ability of U.S. industry to participate in these markets. The Secretary [of Energy] is to report to the Appropriations Committees of the House and Senate within six months after the date of enactment of this Act on potential coal technology export markets and the financing mechanisms and/or levels of Federal government support necessary to assist U.S. industry participation in these markets. In addition, the managers expect the Secretary to consider input from U.S. industry in order to assess the potential for U.S. industry participation in the development of clean coal technology projects in the developing countries and countries with economies in transition.

This provision relates to Section 1332 (Innovative Clean Coal Technology Transfer Program) of the Energy Policy Act (Public Law 102-486). That Section defines an international technology transfer program involving financial assistance for Clean Coal Technology (CCT) projects in the developing and transitional countries.

\section{MARKETS FOR CLEAN COAL TECHNOLOGIES}

The Energy Information Administration (EIA) expects world coal consumption to increase by 30 percent between 1990 and 2010, from 5.1 to 6.5 billion short tons. ${ }^{2}$ Five regions stand out as major foreign markets for the export of U.S. clean coal technologies:

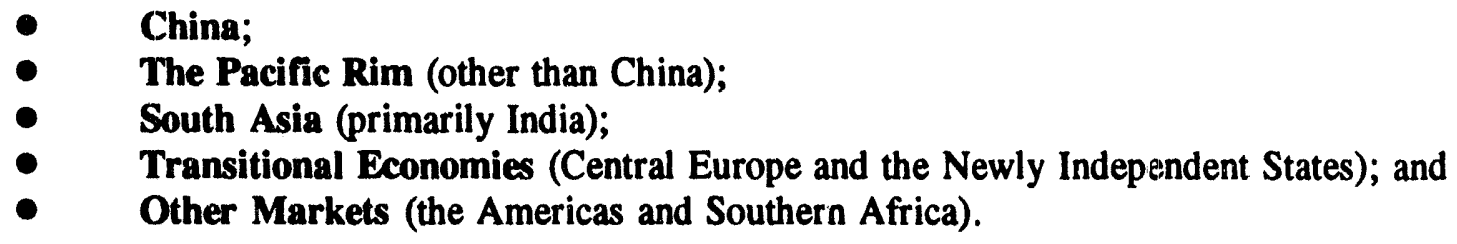

Nearly two-thirds of the expected worldwide growth in coal utilization will occur in China, one quarter in the United States, and the remainder mostly in developing countries, primarily those of the Pacific Rim and South Asia. China is the world's largest coal consumer, and EIA forecasts nearly a billion tons per year of additional coal consumption in China between 1990 and 2010, a virtual doubling of that country's

1 H.R. Conf. Rep. No. 103-299, 103d Congress 1st Sess. (1993)

2 Energy Information Administration, International Energy Outlook 1993, DOE/EPA-0484(93), Washington, DC, April 1993, p. 27. 
coal consumption. A 30-percent increase in coal consumption is projected in other developing countries over that same period. This increase in coal consumption will be accompanied by an increase in demand for technologies for burning coal cost-effectively, efficiently and cleanly.

In the Pacific Rim and South Asia, rapid economic growth coupled with substantial indigenous coal supplies combine to create a large potential market for CCTs. In Central Europe and the Newly Independent States, the challenge will be to correct the damage of decades of environmental neglect without adding to already-considerable economic disruption. Though the situation varies, all these countries share the basic need to use indigenous low-quality coal cleanly and efficiently.

\section{China and the Pacific Rim}

China is the largest potential market for clean coal technologies in the world, due to the great magnitude of its projected coal use, which will grow to about two billion tons per year by 2010 , about one third of the world's total. Strong economic growth, combined with electric supply problems, are placing the electricity sector under substantial pressure. Even with tremendous growth underway in the power sector, electricity utilization is often inefficient, the environmental performance of power production and energy use is poor, and the majority of the people are still without electricity. CCTs are vital to meeting energy needs while preventing further environmental degradation.

Three other developing nations in the Pacific Rim are primary markets for CCTs: Indonesia and South Korea (using coal imports) and Thailand. The Philippines, Taiwan and Vietnam are also markets. The need for power is expected to grow significantly in these countries. Governments are racing to bring new electric generation capacity on-line. A variety of fuel and technology choices are planned as part of an effort to diversify the fuel supply away from oil towards indigenous resources such as coal, natural gas, hydropower and geothermal energy.

\section{India}

India is a major potential market for CCTs, due to its extensive use of coal. As electricity demand continues to rise, India is planning to bring much new electric generation capacity on-line. Environmental issues were previously given little consideration in power projects, but this is changing. India now requires environmental impact assessments and has environmental regulations specifying limits for emissions and effluent discharge.

\section{Central Europe and the Newly Independent States}

The decline in economic activity since 1989 reduced the needs for electric generation in Central Europe. Coal is the predominant energy source for power generation throughout Central Europe from Poland to Bulgaria, accounting for nearly two-thirds of electric generation. Much of the coal in the region is low 
quality and is burned without environmental controls, resulting in substantial environmental degradation and health problems. The countries of the region are all very interested in CCTs, both to rehabilitate or repower inefficient and polluting power plants and to replace those in too poor condition to be rehabilitated economically.

As in Central Europe, the demand for electricity in the Newly Independent States has declined since the breakup of the Soviet Union. Disruption of internal trade relations, shortages of equipment and spare parts, currency problems, balance of payment difficulties and labor action have all contributed to the fuel shortages ard the declining energy output. Coal will continue to play an important role in meeting the primary energy demand in the Newly Independent States, particularly in Russia, Kazakhstan and Ukraine. Environmental issues, which were previously ignored, are now being integrated into power sector policies. CCTs are now being considered to help reduce the environmental impact of coal-fired plants. Under the current economic situation, it is unlikely that these countries will be able to finance the investments themselves. As a result, they will look to foreign sources of capital.

\section{Other Markets}

CCT opportunities also exist in Latin America and Africa. While Mexico and Brazil are planning to increase coal's share in total capacity mix, coal will continue to play a marginal role in meeting the electricity needs of most Latin American Countries because they have other abundant resources such as hydropower. The Republic of South Africa and the member states of the Southern African Development Community (SADC) ${ }^{3}$ are the primary markets for CCTs in Africa. South Africa and several SADC nations (especially Botswana, Mozambique, Swaziland, Tanzania, Zambia, and Zimbabwe) have coal reserves and are experiencing economic growth. The SADC member nations and the RSA are pursuing electrification of the Sub-Sahara region of Africa. Sub-Sahara Africa has about 150 million people within its borders and only about 10 percent of the population is tied to electrical supply. If electrification of this region is realized, a large demand for coal technologies could be created.

\section{FINANCING MECHANISMS FOR CLEAN COAL TECHNOLOGY PROJECTS}

The economies and power sectors of the developing and transitional countries that are the primary international market for CCTs are changing rapidly. Financing of international CCT projects are particularly complex because the projects require very large capital investments with long lead times in high-risk countries. Two types of financing include: the financing of the preliminary activities and the financing of the construction of the project itself.

${ }^{3}$ Member nations of the Southern African Development Community are Angola, Botswana, Lesotho, Malawi, Mozambique, Namibia, Swaziland, Tanzania, Zambia and Zimbabwe. 
Preliminary activities include prefeasibility and feasibility studies, and project definition activities. Private financing for these preliminary activities is limited because of the high risk. Multilateral development banks provide financial resources for prefeasibility studies. The Trade and Development Agency, Agency for International Development, the Export-Import Bank (EximBank) and the Overseas Private Investment Corporation (OPIC) provide funds for financing preliminary activities. Funding of preliminary activities is extremely cost-effective; outlays from $\$ 5,000$ to $\$ 5$ million can result in contracts worth over $\$ 100$ million. The cost of the studies is repaid once the U.S. firm has been awarded the project and financing is completed.

Three types of financing may be used for power plant projects. General credit is the most often used and preferred method for utilities with excellent credit histories. General credit gives the lender recourse to the entire revenues and assets of the borrower as a warranty, which may be the utility and/or the government. Official credit refers to loans, guarantees and grants from multilateral banks and developed country governments. This credit is likely to remain a major source for many developing countries. Project finance is nonrecourse borrowing where the lenders are repaid based solely on the revenues of the project. Project finance is the preferred method for independent power development and is likely to be the method most often used for projects involving U.S. CCTs.

\section{Potential Levels of U.S. Government Support}

U.S. Government financial assistance will be needed for both preliminary activities and the financing of the power plant projects. An estimate was made of the potential annual export credit assistance that U.S. industry could seek from the U.S. Government for the export of clean coal technologies. Total Federal support is estimated at between $\$ 1.1$ and $\$ 2.9$ billion per year. Of this, roughly ten percent is devoted to the preliminary activities, while 90 percent is devoted to the financing of the projects themselves in the form of loans or loan guarantees by EximBank and OPIC. OPIC also has the ability to participate in equity financing.

Project finance of international power projects is relatively new. As more projects utilize project financing and the country and commercial risks become acceptable, this financing structure is being increasingly used for international power projects. Since project financing highly leverages the equity through increased debt, great demands are placed upon the export credit agencies for both resources and debt funding.

The rapid economic growth in Asia, the need to revitalize facilities in Central Europe and the increasing share of debt financing per project will result in an increased demand for funds of U.S. export credit agencies. In addition, there will be greater competition for capital between energy and other infrastructure projects. As countries develop, the risk decreases and private funding sources will displace the need for export credits. Federal export credit agencies will need to develop considerable new capability and expertise in order to process the anticipated number of project finance transactions. 


\section{IMPLEMENTATION OF INTERNATIONAL CLEAN COAL TECHNOLOGY TRANSFER}

As part of the President's FY 95 budget request, the U.S. Department of Energy (DOE), Office of Fossil Energy proposed an approach to implement the provisions of Section 1332 of the Energy Policy Act of 1992. This approach was developed after extensive discussions and consultation with industry and other interested Federal agencies. Implementation of Section 1332 is part of a broader effort to assist U.S. industry to participate in the expanding international market for CCT and to commercialize U.S. technologies for the mutual benefit of the United States and its trading partners.

This program is being coordinated with several ongoing Federal export initiatives. The National Export Strateay is a coordinated Federal export strategy with clear actions for measurable results. The Strategic Framework for Environmental Technologies Exports complements the National Export Strategy and focuses on environmental technologies, including CCTs. Joint Implementation for Global Climate Change refers to cooperative agreements between parties from different countries to reduce greenhouse gas emissions under the Framework Convention on Climate Change. The Administration has announced a pilot program for joint implementation - the U.S. Initiative on Joint Implementation - to help establish an empirical basis for considering approaches to joint implementation.

\section{Planned Approach to Technology Transfer}

The proposed coal technology transfer activities consist of three basic elements within the overall context of the Fossil Energy International Strategic Plan. These elements are education and technical support, "showcase" projects of advanced U.S. coal technologies, and a fund for sharing the costs of project definition activities for commercial technologies. U.S. industry support for this approach was evidenced by the positive comments of the approximately 250 industry attendees at a public meeting conducted February 10 and 11,1994 . The purpose of this meeting was to provide a public forum for comment on DOE's analysis of the CCT market and the proposed approach to implementing Section 1332. The underlying basis for the program approach is to highly leverage minimal government funds with private sector investment to position U.S. technologies and companies at the leading edge of key growth markets. A relatively small investment (less than 5 percent of the domestic CCT program) can result in several billion dollars of annual exports.

The three elements of the proposed approach are explained below:

1) Education and technical support will be provided to U.S. industry, export credit agencies, multilateral banks, and governments and industry of potential market countries. This effort will inform the potential user of the economics and performance of U.S. CCTs and provide opportunities for U.S. industry to meet the decision makers in the foreign markets.

2) Showcase projects will highlight the cost-effectiveness of advanced U.S. clean coal technologies in developing and transitional countries. These will be developed in partnership with U.S. 
industry and host country stakeholders and will involve construction and operation of projects with U.S. advanced technologies. For the purpose of this program, "advanced technologies" are those that have been proven through demonstration in the U.S., but have not yet achieved adequate commercial U.S. replication for the financial markets to warrant commercial backing.

The Department has requested funding in the FY 1995 Budget to initiate showcase clean coal technology demonstration projects in China and Central Europe aimed at reducing the risk of building proven advanced technologies in countries with little previous experience using the technology. The new $\$ 75$ million initiative calls for DOE to provide financial assistance of 10 to 25 percent of project capital costs. An amount well in excess of the U.S. Government assistance would be returned to the U.S. market through equipment sales to the showcase projects.

Two markets stand out as prime candidates for early showcase projects: China which has a large need to increase coal-fired power generating capacity over the next fifteen years, and Central Europe which needs technologies to upgrade the performance of existing coal fired facilities. Developing clean coal showcase projects in China and Central Europe will contribute to the effort defined by the Joint Implementation Initiative, which is an important part of the President's Climate Change Action Plan.

3) Cost-sharing of definitional studies for commercial projects will fill a gap in the current Federal support of U.S. companies developing power projects in foreign countries. Only prefeasibility and feasibility studies receive support that recognizes the greater risk of preliminary activities, not the subsequent definitional activities, that are more expensive and still risky.

DOE's program would provide cost-sharing of project definition activities for technology that is commercial in the U.S., but not in the host country. Funds for these activities would be available through DOE-sponsored project definition activities. The activities to be cost-shared could include sufficient engineering and design to support an adequate cost estimate for financing, developing supply and sales agreements, and defining risks and approaches to mitigate them.

\section{Incorporation of Industry Comments}

The DOE has engaged in an extensive dialogue with U.S. industry for more than two years on the subject of CCT exports. The dialogue has included extensive ongoing discussions with CCT project developers, equipment manufacturers and supporting industries including the financial community. These discussions led to both Fossil Energy international activities generally and the development of the draft plan for Clean Coal International Technology Transfer. This draft plan was reviewed in detail with approximately 200 industry representatives at a public meeting held in Washington D.C. on February 10 and 11, 1994. The suggestions and comments received in these two forums have greatly shaped DOE's plans for implementation of the coal technology transfer program. 


\section{Chapter 1}

\section{INTRODUCTION}

The United States Congress requested that the Secretary of Energy report to Congress on potential coal technology export markets and financing mechanisms for the markets. Specifically, the Congressional Conference report ${ }^{1}$ states that:

That \$625,000 in coal technology export is for initial implementation of section 1332 of the Energy Policy Act of 1992. The managers expect that the funding provided will be used by the Department to identify potential markets for clean coal technologies in developing countries and countries with economies in transition from nonmarket economies and to identify existing, or new, financial mechanisms or financial support to be provided by the Federal government that will enhance the ability of U.S. industry to participate in these markets. The Secretary is to report to the Appropriations Committees of the House and Senate within six months after the date of enactment of this Act on potential coal technology export markets and the financing mechanisms and/or levels of Federal government support necessary to assist U.S. industry participation in these markets. In addition, the managers expect the Secretary to consider input from U.S. industry in order to assess the potential for U.S. industry participation in the development of clean coal technology projects in the developing countries and countries with economies in transition.

This report fulfills these requirements. Chapter 2 describes the potential international markets for coal technologies and how technologies are selected in these markets. Chapter 3 defines the types of financing mechanisms that will be used for international coal technology projects and makes rough estimates of the levels of Federal support necessary to assist U.S. industries participating in these markets. Chapter 4 describes current plans for the implementation of international Clean Coal Technology (CCT) transfer programs and how the industry input was obtained and is being incorporated.

\section{SIGNIFICANCE OF CLEAN COAL TECHNOLOGY EXPORTS}

Exports of CCTs and development of these projects promise to create a major potential market for U.S. goods and services over the next twenty years. As described later in this report, $\$ 718$ billion may potentially be spent on coal utilization projects by 2010 , of which $\$ 207$ billion may be realized by exporters of these technologies. If this potential is realized, it could create 69,000 jobs in all the exporting countries. The U.S. is the world leader in CCTs. Securing a significant portion of the market will substantially improve the U.S. balance of trade and provide thousands of jobs to U.S. workers. The development of adequate financing mechanisms for U.S. firms, as described in this report, is crucial to achieving this potential.

${ }^{1}$ H.R. Conf. Rep. No. 103-299, 103d Congress., 1st Sess. (1993). 
Coal utilization is expected to grow throughout the world. China is already the world's largest user of coal and its coal requirements are projected to grow to 2 billion tons in the year 2010. Most Chinese coal consumption, however, is highly inefficient and environmentally damaging, a situation that is typical of most of the developing world. For example, coal is currently the major energy source in Central Europe and the Newly Independent States. Yet, often it is burned with little or no control of pollutants. Large-scale coal utilization in Central Europe is expected to continue, driven by electric generation requirements. The rapidly-industrializing Asia-Pacific Region (including India) will also greatly increase its coal use. Economic growth and electrification of Africa, especially southern Africa, are expected to expand the use of coal on this continent. Similarly sustained economic growth in Latin America will increase coal demand, although use of other energy sources is expected to grow faster in this region. Many industrialized countries use coal and have established CCT industries. Coal will continue to play an important role, for example, in Western Europe. Coal demand in all of these markets will be significantly affected by both growing energy needs and environmental concerns.

\section{RELEVANT ENERGY POLICY ACT PROVISION}

This report describes the implementation of Section 1332 (Innovative Clean Coal Technology Transfer Program) of the Energy Policy Act (Public Law 102-486, 42 U.S.C. 13362, "EPACT"). This section describes a technology transfer program for creating jobs and reducing the trade deficit for the United States, through providing financial assistance for projects to improve energy efficiency and reduce environmental emissions including "greenhouse gases." These projects are to be located in countries which are supported by the Agency for International Development (A.I.D.) or in countries with an economy in transition from a non-market to a market economy. Working with A.I.D., the DOE is to: 1) complete in $\mathbf{1 5 0}$ days an agreement with the appropriate U.S. agencies for conducting the program in the host countries; 2) issue in 240 days a list of potential projects; 3 ) issue a solicitation within one year and 4) make a selection within 120 days after receipt of proposals. In addition, the programs are to develop a procedure for providing financial assistance to projects applying for solicitations in other countries.

Section 1332 of the EPACT establishes the Innovative Clean Coal Technology Transfer Program. This program is designed to encourage the exports of U.S. CCTs and services to countries that have a need for these technologies. The Secretary of Energy, through the Agency for International Development and in consultation with the other members of the Clean Coal Technologies Subgroup of the Trade Promotions Coordinating Committee, is to establish the Innovative Clean Coal Technology Transfer Program under Section 1332. Financial mechanisms are to be developed and utilized to increase participation of U.S. firms in the CCT market in developing countries and in countries in transition to a market economy. Additionally, financial assistance is to be used to counterbalance assistance provided by foreign governments to non-U.S. firms. Section 1332 authorized $\$ 100$ million for each of the fiscal 
years 1993 through 1998 to conduct this program. These funds, however, have not yet been appropriated for the program.

\section{RELATED NITIATTVES}

The activities described in this report are being coordinated with several ongoing Federal export promotion initiatives. These include the National Export Strategy, developed by the Trade Promotion Coordinating Committee; the Strategic Eramework for Environmental Technologies_Exports, developed by the Environmental Technologies Export Working Group and the White House Office of Environmental Policy; and the U.S. Initiatives Joint Implementation on Global Climate Change.

The focus of the Nitiond Ixport Strntegy is on diveloping a coordinated strategy with clear actions for measurable results, for the both near and long term. Key to the process is involvement of business, the financial community, government agencies and the public.

The National Export Strategy will create a unified export promotions budget and coordinate export promotion activities among the many Federal agencies involved in them. A comprehensive commercial strategic plan for each country with significant market potential will be developed. A Trade Promotions Coordinating Committee (TPCC) Advocacy Coordinating Network will inform U.S. businesses of overseas opportunities. And finally, the National Export Strategy will increase understanding of export financing among potential exporters, involve more banks, broaden access to governmental export financing institutions and level the playing field.

DOE's activities to promote the export of CCTs are being implemented within the framework of the National Export Strategy. Most importantly, a Clean Coal Technology Subgroup of the TPCC has already been established with members from eleven Federal agencies. Within this framework, coordination will take place in areas related to resource allocation, the provision of export promotion services, export financing (particularly related to international project finance) and the removal of regulatory obstacles to exports.

The Strntexic Frnmework for Environmental Technologies Exports complements the National Export Strategy and is founded on the guiding principles of environmental stewardship, sustainable development, constructive business-government partnerships and effective and accountable government.

Clean Coal Technology is a key element of this strategic framework. It will reduce pollution in regions of the world where uncontrolled coal combustion already has caused problems and will minimize pollution in regions where coal use is expected to grow. 
Joint Implementation on Global Climate Change refers to a cooperative agreement between two parties from different countries to reduce greenhouse gas emissions. Joint Implementation falls under the Framework Convention on Climate Change (the Climate Convention).

Developing countries and economies in transition have an enormous potential for cost-effective greenhouse gas emission reductions. The Administration has announced a pilot program - the U.S. Initiative on Joint Implementation - to help establish an empirical basis for considering approaches to joint implementation. The initiative will provide mechanisms for investments by U.S. firms and for potential government assistance for net greenhouse gas emissions reductions to be evaluated. The purpose of this initiative is to help establish an empirical basis for considering approaches to joint implementation and thus help realize the enormous potential for joint implementation both to combat the threat of global warming and to promote sustainable development. The initiative will establish an interagency evaluation panel to certify net emission reduction estimates from qualified projects.

A wide range of options are available to reduce greenhouse gas emissions. These options reflect the many potential opportunities for improvement. By increasing efficiency, U.S. CCTs can greatly help many countries reduce growth in greenhouse gas emissions.

\section{CLEAN COAL TECHNOLOGIES FOR DEVELOPING AND TRANSITIONAL COUNTRIES}

Since technical and financial resources in developing and transitional countries are constrained, only those technologies that have been widely proven in a commercial setting are generally given serious consideration. The current CCT portfolio includes a wide range of innovative approaches for reducing emissions and improving efficiency. Some of these technologies are still under development. In other cases, full-scale demonstration facilities are operating successfully. Still other CCTs are already in widespread commercial use. As technical progress continues, advanced CCTs become commercial and innovative CCTs become conventional. In fact, most coal technologies used domestically today would have recently been considered highly advanced. Additional progress and experience expands the spectrum of exportable technologies. As described in Chapter 5, this progression plays an important role in DOE's strategy for international technology transfer.

\section{BENEFITS FOR THE U.S. AND ITS FOREIGN PARTNERS}

The primary direct economic benefits to the U.S. arising from the participation in world CCT markets are an improved balance of trade and employment gains. These benefits will be realized through the export of U.S. goods and services and through foreign direct investment by U.S. companies. In addition, U.S. industry will remain more competitive in both foreign and domestic markets, and the economic, energy and environmental benefits to our foreign trade partners will contribute to a more stable 
environment in which to condu.t U.S. foreign policy. CCTs provide the U.S. with the capability to strategically enhance U.S. competitiveness in a rapidly expanding market.

International orders for capital equipment, such as CCTs, would positively impact the U.S. economy over the long-term. Foreign buyers of U.S. CCTs are likely to return to the original suppliers for future additions to capacity. American companies also gain from the sale of replacement parts and operating and maintenance support. Over time, these ongoing expenditures can equal or exceed the original investment. Further, U.S. companies gain the reputation of having supplied the latest state-of-the-art technology, resulting in a more visible and profitable market position. Consequently, CCT exports today will help ensure U.S. market position and future international strength.

Increased U.S. presence in the international CCT market will also result in significant job growth. Potential worldwide investment of $\$ 718$ billion could result in the potential creation of 69,000 new export-related jobs in all the exporting nations. ${ }^{2}$ Bringing a large share of these jobs to the U.S. would strengthen the U.S. competitive position by increasing aggregate demand for domestic goods and services, thus benefitting sectors of the economy not directly related to clean coal or energy industries.

U.S. investment in CCTs in foreign countries benefits the U.S. economy in a variety of ways. From the U.S. investor's perspective, foreign investment represents a way to improve the investor's position in key markets. Foreign plants, for example, open new export opportunities for other U.S.-produced goods, as new distribution channels are opened and foreign consumers become more familiar with U.S. products. To the extent that profits flow home and the U.S. companies grow and invest domestically, the U.S. captures economic benefits. In addition, U.S. foreign direct investment allows U.S. firms access to the intellectual capital in the project, offering opportunities to expand the technology base of the company and the U.S.

The market for CCTs is global: conducting business successfully on a worldwide basis is necessary to be competitive, even in domestic markets. In a global market, the deployment of advanced technologies anywhere expands the technical and economic data base on these technologies, thus allowing a wider range of applications in all countries, including in the United States. Moreover, a greater number of projects worldwide reduces technical risk, and also makes it easiez for advanced technologies to gain acceptance in the financial markets.

Clean coal technologies offer many countries the opportunity to match these environmentally superior, more efficient technologies to their increasing electricity requirements. In addition to new construction, these advanced technologies can be used to repower aging boilers and retrofit existing power generation equipment for the most cost-effective solutions to environmental problems. Employing these technologies

${ }^{2}$ Resource Dynamics Corporation, "Market Potential for Clean Coal Technologies Exports: Updated Estimates", Report to the U.S. Department of Energy, October 1, 1993. 
can help resolve the environmental problems associated with coal use without sacrificing economic imperatives. Benefits of U.S. CCTs include:

- Environmental Advantages. CCTs minimize the environmental impacts associated with growth or previous environmental neglect by reducing potentially harmful emissions. CCTs cost-effectively reduce solid wastes and the emission of $\mathrm{SO}_{2}, \mathrm{NO}_{\mathrm{x}}$, particulates and "greenhouse gases."

- Energy Self-reliance. CCTs offer developing nations increased fuel flexibility by accommodating low-grade domestic coal, lignite or peat reserves, while increasing energy self-reliance.

- Economic Development. Nearly all overseas CCT projects utilize large quantities of local labor and supplies, thus increasing local employment. Increased employment raises aggregate national income, benefitting all sectors of the host country's economy. CCTs under development will have the ability to upgrade low-ranking domestic supplies for export markets, benefitting the host nation's balance of trade. These benefits can facilitate the development of domestic mining industries, further expanding employment in developing countries.

- Electrification. By allowing for the use of local resources, CCTs help make electrification economically feasible in developing countries. Electrification offers benefits in the form of modernization, economic growth, improved quality of life, job growth, and increased industrial efficiency and domestic output.

- Energy Efriciency. Advanced power systems can improve power generation efficiency by $20-30$ percent, resulting in a corresponding reduction in requirements for resources and infrastructure.

- Access to Capital. Importing U.S. CCTs allows foreign countries to qualify for a wide range of assistance from multilateral financial institutions and U.S. government export assistance programs. Increasingly, U.S. export finance agencies and multilateral financing institutions such as the World Bank require that developing nations meet stringent environmental standards as a condition for obtaining the financing. U.S. CCTs will allow these standards to be met.

- Debt Reduction. Equity participation by U.S. firms in new projects offers developing countries an opportunity to raise capital without increasing their often substantial foreign debt, or sacrificing hard currency.

- Political Stability. Economic growth enhances political stability and is brought about by domestic and U.S. investment, jobs, and the benefits of electrification. 


\section{RELATED REPORTS}

Over the last two years, DOE has prepared several reports to Congress addressing issues related to the export of clean coal technologies. These reports provide greater detail of some of the issues covered in the present report.

World Markets for U.S. Clean Coal Technologies ${ }^{3}$ was written as part of the 1992 National Energy Strategy. It describes the international markets for CCTs and makes recommendations for the development of a CCT export initiative. Several of these recommendations have already been incorporated in the activities of DOE and other Federal agencies.

Clean Coal Technologies Export Finance Programss ${ }^{4}$ describes the financing of international CCT projects including prefeasibility studies, feasibility studies, and the CCT project itself. Chapter 3 of the present report is partially based on this report.

Foreign Markets for U.S. Clean Coal Technologies ${ }^{5}$ profiles the high potential Clean Coal Technology markets. Chapter 2 of the presert report is partially based on this report.

Market Potential for Clean Coal Technology Exports ${ }^{6}$ develops detailed estimates for worldwide Clean Coal Technology investments between 1993-2010. It also develops estimates of the export potential and related job creation opportunities created by these exports.

U.S. Department of Energy Proceedings of the Public Meeting on International Clean Coal Technology Transfer, February 10-11, 1994, Forthcoming.

${ }^{3}$ U.S. Department of Energy, "World Markets for U.S. Clean Coal Technologies", Report to Congress, September 1, 1992.

${ }^{4}$ U.S. Department of Energy, "Clean Coal Technologies Export Finance Programs", Report to Congress, September 30, 1993.

5 U.S. Department of Energy, "Foreign Markets for U.S. Clean Coal Technologies", Report to Congress, In Progress.

${ }^{6}$ Resource Dynamics Corporation, "Mar!et Potential for Clean Coal Technologies Exports: Updated Estimates", Report to the U.S. Department of Energy, October 1, 1993. 
These reports may be obtained from:

\author{
U.S Department of Energy \\ Office of Fossil Energy \\ Office of Communication (FE-5) \\ Washington, DC 20585 \\ (202) 586-6503
}




\section{Chapter 2}

\section{MARKETS FOR CLEAN COAL TECHNOLOGIES}

World coal consumption is expected to increase by 30 percent over the next twenty years. For example, the Energy Information Administration (EIA) projects an increase between 1991 and 2010 in its base case forecasts from approximately 5.1 to 6.5 billion short tons. ${ }^{1}$ Increased coal use, coupled with growing environmental concerns, will create markets for clean coal technologies (CCTs) throughout the world over the next twenty years. Coal resources provide an abundant, secure and economic source of energy for many countries and these countries plan to use these resources to satisfy their energy needs. Clean coal technologies allow coal to be used economically, efficiently and with greatly reduced emissions.

This chapter describes the international markets for CCTs and discusses how various economic, technical and institutional factors influence the choice of clean coal technologies in these markets. The AsiaPacific region and the transitional countries will be the major foreign markets for the export of U.S. clean coal technologies, but other markets could also be significant. The following markets in developing and transitional countries are discussed:

\section{Asia Pacific \\ - China; \\ - The Pacific Rim (other than China); and \\ - South Asia (primarily India).}

\section{Transitional Economies}

- Central Europe; and

- The Newly Independent States of the former Soviet Union.

\section{Other Markets}

- Latin America; and

- Southern Africa.

Nearly two-thirds of worldwide growth in coal utilization expected by EIA will occur in China, one quarter in the United States, and the remainder mostly in developing countries; primarily those of the Pacific Rim and South Asia. China is the world's largest coal consumer. EIA forecasts that annual consumption in China will increase by about one billion tons in China between 1990 and 2010, a virtual doubling of that country's coal consumption. A 30-percent increase in coal consumption is projected in other developing countries over that same period. This increase in coal consumption will be accompanied by an increase in demand for technologies for burning coal cost effectively, $\epsilon$.ficiently and cleanly.

\footnotetext{
' Energy Information Administration, Intemational Eneroy Outlook 1993, DOE/EIA-0484(93), Washington, DC, April 1993, p. 27.
} 
Developing and industrialized countries are both expected to expand their coal use. Economic growth in many nations will be based on coal, the dominant energy source for many developing countries. Coal will increase its share of total primary energy consumption, especially in nations seeking to increase domestic energy consumption. Energy policies in many countries seek to accomplish these objectives and to increase energy self-reliance by developing domestic coal-mining industries.

In China and Central Europe, coal has long been the dominant energy source, providing 77 percent of primary energy consumption in 1990 in China and 61 percent in Central Europe. Coal also accounts for 20 percent of primary energy use of the Newly Independent States (NIS). ${ }^{2}$ Economic progress will continue to depend on coal in all these countries. In the NIS, oil production is forecast to decline and some oil and gas will be exported to earn harc' currency, leaving much domestic energy growth to be served by coal. Coal consumption in the NIS, however, is expected to remain flat over the next 20 or so years due to economic restructuring that will emphasize less energy-intensive industries and improved efficiency. In Central Europe and the NIS, the challenge will be to correct the darnage of decades of environmental neglect without adding to already-considerable economic disruption. In the Pacific Rim and Southern Asia, rapid economic growth coupled with substantial indigenous coal supplies combine to create a large potential CCT market. In addition, many industrialized countries are already large coal users and will be significant markets for CCTs. Though the situation varies, all countries share the basic need to use coal cleanly and efficiently.

Electricity generation is currently the largest use of coal throughout the world. In addition, most of the worldwide growth in coal use is anticipated in this sector. China, the Pacific Rim and India are expected to be particularly large markets. During the next decade, large numbers of new coal-fired power plants are planned in these regions. DOE projects that worldwide, 473,000 MW of existing coal-fired generation capacity could be retrofit with CCTs between 1993 and 2010, and 382,000 MW of new coalfired generation capacity, designed with clean coal technologies, could be developed. ${ }^{3}$ Most of this market is in developing and transitional countries, 388,000 MW of retrofits and 334,000 MW of new capacity (Table 2-1). China alone accounts for about 27 percent of the potential worldwide retrofit market, and 54 percent of the growth market.

Other uses of steam coal, particularly for residential space heating is alsc significant in China, the NIS and Central Europe. Many major cities, which are served by district heating often use combined heat and power (cogeneration) plants. Much of this has little environmental control. Except in China, these uses may decline with economic restrictions, fuel switching, and increased efficiency.

\footnotetext{
${ }^{2}$ Energy Information Administration, International Energy Annual 1991, DOE/EPA-0219(91), Washington DC, January 1993.

${ }^{3}$ U.S. Department of Energy, Office of Fossil Energy, Market Potential for Clean Coal Technology Exports, Updated Estimates, Washington DC, October 1, 1993.
} 
At the same time that coal consumption will be growing in most of the major markets, a higher priority will be placed upon environmental concerns throughout the world. Emissions from the combustion of coal and other fossil fuels have been cited as a major contributor to several environmental problems, ranging from smog to acid rain and global climate change.

\section{TABLE 2-1}

\section{POTENTIAL CCT MARKETS IN DEVELOPING AND TRANSITIONAL COUNTRIES, 1993-2010 (Gigawatts)}

\begin{tabular}{|l|r|r|}
\hline \multicolumn{1}{|c|}{ Region } & Retrofits & \multicolumn{1}{c|}{$\begin{array}{c}\text { New } \\
\text { Applications }\end{array}$} \\
\hline Transitional Economies & 175.6 & 11.3 \\
Central Europe & 79.8 & 0 \\
Former Soviet Union & 95.8 & 11.3 \\
Developing & 212.1 & 322.7 \\
China & 125.8 & 204.4 \\
South Asia & 46.1 & 73.8 \\
Developing Pacific Rim & 7.9 & 34.3 \\
Latin America & 3.9 & 1.2 \\
Africa & 28.4 & 9.0 \\
Total Transitional and Developing & 387.7 & 334.0 \\
\hline TOTAL WORLD & 473.2 & 381.8 \\
\hline
\end{tabular}

SOURCE: Basod on U.S. Department of Energy, Office of Fossil Energy, Market Potential for Clean Coal Technology Exports, Updated Eatimates. Workine Paper, Washington DC, October 1, 1993.

The EIA estimates total carbon emissions worldwide from the combustion of fossil fuels to be 6 billion tons in 1990, rising to 8 billion tons in 2010. ${ }^{4}$ Of these totals, 2.3 billion tons and 3.0 billion tons are directly attributable to coal combustion in 1990 and 2010, respectively. Many countries have begun to take steps to limit emissions from coal combustion. The higher efficiencies of the new CCTs provide a means to limit carbon dioxide emissions.

Environmental concerns are particularly pressing in Central Europe and the NIS. Years of reliance upon low-quality, heavily polluting indigenous coal resources have taken a heavy toll upon the land and the people of these regions. As these nations seek to form business and economic alliances with the Western institutions such as the European Economic Community, they will come under increasing pressure to conform to minimal environmental standards. China faces similar environmental problems (particulate emissions, smog induced by nitrogen oxides, wasted resources, sulfur dioxide emissions and greenhouse gases) and these will be exacerbated by strong economic growth. Other countries are also seeking to

\footnotetext{
4 Energy Information Administration, International Energy Outlook 1993, p. 34.
} 
balance economic growth with concerns about the environment. For many countries, CCTs offer a way to minimize the environmental impacts associated with growth or previous c.nvironmental neglect.

\section{ASIA-PACIFIC REGION}

The Asia-Pacific region is the fastest-growing market for clean coal technologies and consists of four dis.inct regional markets: China, the Developing Pacific Rim, the Developed Pacific Rim, and South Asia.

\section{Ching}

China, with the largest population in the world, is on a path of strong economic growth. The political and economic structure is in flux with the introduction of economic incentives, however, creating great uncertainty for the future. Between January 1993 and January 1994, industrial output increased by 33.2 percent while the economy grew by 12.1 percent 5 .

China is the third largest energy producer in the world and the largest coal consumer. Energy production grew 63 percent in the 1980s and is expected to grow an additional 39 percent in the 1990s. Electric power generation grew 127 percent in the last decade, from 300 billion $\mathrm{kWh}$ in 1980 to $680 \mathrm{kWh}$ in 1991. Almost two-thirds of the power China produces is used in the industrial sector, a much higher share than in developed countries, India or the Newly Independent States. The domestic sector has relatively little electricity now available to it and the potential for growth is great. Chronic power shortages still exist.

Coal dominates power generation in China, accounting for nearly three-fourths of the power generated in 1991 (501,550 Gigawatt hours). In 1993, total generating capacity was approximately $177 \mathrm{GW}$, eighty percent of which was thermal

EIA BASE CASE PROJECTIONS FOR COAL CONSUMPTION IN CHINA (Million Short Tons)

\begin{tabular}{|l|c|c|c|}
\hline & $\begin{array}{c}1991 \\
\text { Actual }\end{array}$ & $\begin{array}{c}2000 \\
\text { Projected }\end{array}$ & $\begin{array}{c}2010 \\
\text { Projected }\end{array}$ \\
\hline Chin & 1,192 & 1,685 & 2,133 \\
Worid & 5,102 & 5,789 & 6,479 \\
\hline
\end{tabular}

SOURCE: Energy Information Agency, International Enerey Outlook 1993, DOE/EIA-0484(93), Washington D.C., April 1993. and 20 percent hydropower. Coal-fired power plants account for about 70 percent of total electricity supplies. This heavy emphasis on coal for power generation is expected to grow in the years ahead as China moves to exploit its abundant domestic coal resources. As the world's largest coal consumer, China should be responsible for most of the growth in world coal use at least through 201C. According to EIA projections, the growth in coal in China

\footnotetext{
SThe Economist, "Emerging Market Indicators," March 12, 1994, pg. 126.

' Intermational Eneray Azency, Energy Statistics and Balances of Non-OECD countries, 1990-91, Page 171, 1993.
} 
between 1991 and 2010 represents two-thirds of the increase in world coal consumption during that period, highlighting the potential opportunities for clean coal technologies in China.

Coal is widely used for many other purposes, the largest of which is industrial uses. In 1990, more coal was used in the industrial sector than for power generation. Most of the industrial uses are in coking coal for the production of iron and steel. Coal is also widely used for space heating and cooling in residential applications.

\section{Planned Generating Capacity Additions}

Forecasts of power plant expansion needs are large. On average, power demand is projected to grow by 8 percent per annum. Currently, demand is estimated to exceed supply by 20 percent due to a number of factors, including low energy prices, a large number base of existing power plants, outdated management practices and transportation bottlenecks. The rail system is close to reaching capacity and this greatly limits the ability to move coal to growing electric load centers. At present 60 percent of total rail transportation is dedicated to coal, placing heavy burdens on the rail network and limiting rail service for other purposes.

Rapid expansion of the electricity supplies is essential to sustaining economic growth. Over the last three years, China has brought new capacity on-line at a rate of $1,000 \mathrm{MW}$ per month, and hopes to install an additional $125 \mathrm{GW}$ in the next seven years. ${ }^{7}$ Primarily coal-fired thermal- (greater than $600 \mathrm{MW}$ ) and hydro-power will be developed; some nuclear power will be developed in coastal areas with scarce energy resources. To avoid exacerbating existing coal transportation constraints, many new coal-fired power plants will be mine mouth projects.

This planned expansion will bring total installed capacity to $300 \mathrm{GW}$ by 2000 , and require $\$ 100$ billion of investment. China can finance 75 percent of this investment from internal resources, leaving \$25 billion to be raised by foreign investors. This investment is divided between equipment for generation, transmission and distribution.

\footnotetext{
7 T. Aixing, "A Review of Developments in Key Markets - People's Republic of China, "Proceedings of the Conference on Private Power in China, San Francisco, Califomia, Feb. 7-8, 1994.

Ibid, note 7.
} 
China is currently moving toward decentralization of financing authority for infrastructure projects and encouraging independent power producers to speed i:p their ability to bring new projects on-line. The government is also rationalizing prices for coal, with expectations of free market prices in 3 years ${ }^{9}$ and eliminating subsidies that encourage wasteful use of energy. To encourage foreign investment, China announced debt reform. In July 1993, the government announced the new tariff must cover at least principal and interest payments. ${ }^{10}$ This policy, however, is balanced against the ability of the province to pay the tariff. The capability to repay is the responsibility of the province even when backed by a central bank guarantee. Currently, over 35 projects (each greater than $500 \mathrm{MW}$ ) plan to use foreign loans or joint venture arrangements." The government is also attempting to set policies that will lead to a steady, sustainable growth level in the 6 to 8 percent range for 1994 (down from an estimated 12 to 14 percent in 1993) $)^{12}$ without initiating damaging bouts of inflation.

\section{Potential for Clean Coal Technologies}

China has identified energy conservation, efficiency and enhanced environmental protection as essential components of power sector development. As an example of these new policies, China instructed The Wing Group, which is developing gas projects near Shanghai, that any coal projects would have to be as clean as gas. New projects must comply with the Environmental Protection Law, and old facilities will be rehabilitated.

Other than limited fluidized bed combustion applications, clean coal technologies are not yet widely used in China. Large quantities of coal are used for power generation and other purposes with very few controls. This has resulted in severe environmental problems in some regions. Particulate emissions have caused serious air pollution, and electrostatic precipitators are being installed on existing power plants. China is interested in reducing the environmental impact of power generation without sacrificing its energy efficiency and conservation goals. There is great interest in clean coal technologies because they will enable China to meet these goals. Several commercially-available clean coal technologies are of particular interest to the Chinese: fluidized-bed combustion technology (circulating and pressurized), integrated gasification combined cycle, flue gas desulfurization, and particulate controls. China does not have the capability to manufacture all the equipment needed for it power expansion plans domestically and will need to purchase some equipment from foreign suppliers.

\footnotetext{
Power in Asia, March 29, 1993, Page 8.

${ }^{10}$ Ibid, note 7

11 Ibid, note 7

${ }^{12}$ The Wall Street Joumal, "That Hum You Hear is Asia Growing"; October 18, 1993; Page A-12
} 
Only 23 percent of China's coal use is in electricity generation, compared to 85 percent in the U.S. In order to meet their goal of 35 percent by $2000,{ }^{13}$ the government will also have to work in two other areas: 1) 400,000 small industrial boilers with $55-70$ percent thermal efficiency need to be upgraded by developing central heating systems that combine heat supply with power generation, and 2) introduction of coal briquettes could reduce carbon dioxide by 70-80 percent, smoke dust by 60 percent, coal consumption by 20-30 percent and sulfur dioxide by 50 percent (with a vulcanized agent added). In general, China needs to go from direct and dispersed combustion of coal to efficient use of coal for electricity production. ${ }^{14}$ Future priorities include increased utilization of technologies to achieve efficiency and environmental improvement, elevation of energy prices to encourage efficiency, and integration of energy and environmental planning. In addition, attention is starting to focus on sulfur dioxide and nitrogen oxides emissions in major cities and industrial areas.

\section{Developing Pacific Rim}

The developing Pacific Rim countries include the Association of Southeast Asian Nations (ASEAN) countries of Indonesia, Malaysia, the Philippines and Thailand ${ }^{15}$, as well as Vietnam, Taiwan and South Korea. The need for electricity throughout this region is driven by continued high economic growth in ASEAN countries (and anticipated growth in Vietnam). Over the last two decades the ASEAN region has undergone rapid economic modernization, during which gross domestic product growth rates averaged 6 percent $^{16}$. The U.S.-ASEAN Council forecasts that annual economic growth in these countries will continue at 6.5 percent through $1997^{17}$.

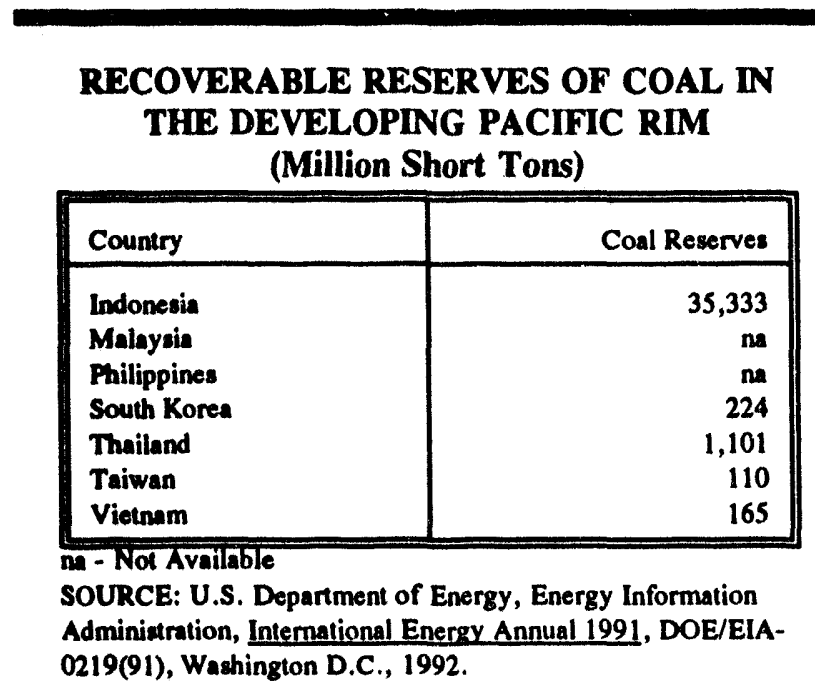

0219(91), Washington D.C., 1992.

\section{Ibid note 12.}

${ }^{14}$ Qu Geping, "China's Dual-Thrust Energy Strategy, Economic Development and Environmental Protection," Energy Policy, June 1992, page 503.

\footnotetext{
is The countries comprising the Association of South East Asian Nations (ASEAN) are Thailand, Indonesia, Malaysia, Philippines, Singapore, and Brunei Darussalam. No discussion of Singapore or Brunei is included because they are unlikely to use Clean Coal Technologies. They are expected to continue using oil, and some gas to meet their energy needs.

${ }^{16}$ Private Power Executive, "Southeast Asia-The Future is Now", July/August 1993.

17 Ibid note 16.
} 
The rapid development is placing heavy demands on existing power systems and power utilities are struggling to keep up. During the late 1980s, per-capita electricity demand expanded rapidly, growing at more than 15 percent annually in Indonesia, 11.4 percent in Thailand, and 4 percent in the Philippines despite recession. Similar demand is expected in the 1990s. Rural electrification, urbanization, and continuing rapid industrialization will fuel this growth. Power demand is growing at 17 percent annually in Indonesia, 10 percent in Malaysia and 10 percent in Thailand. In the Philippines, demand already far exceeds supply, and the country is experiencing chronic brown-outs and power shortages. In 1992, the Philippines' main power grid experienced power outages on 258 days; on 27 days in 1991, and on 101 days in 1990. Even with improving conditions, government estimates show that economic output lost due to inadequate power supply will total $\$ 1$ billion in 1993, 1.7 percent of the country's Gross Domestic Product.

Sustaining the current level of economic growth is a priority for governments in the region. To meet the anticipated power demand ASEAN countries are focusing on increasing installed electric generating capacity. The Asian Development Bank forecasts that capacity additions by 2000 could total 43,273 MW, with nearly 79 percent $(34,100 \mathrm{MW})$ of this expansion occurring in Indonesia and Thailand.

A variety of technology and fuel choices are being planned. Although the situation differs by country, a concerted effort is under way to shift from traditional oil-fired generation toward other significant indigenous resources such as coal, natural gas and renewable energy, including geothermal. This diversification is part of an effort to reduce reliance on a single fuel type and exploit other indigenous energy reserves, which are considerable compared with oil.

Currently, forty-nine percent of installed capacity in the region is conventional steam boilers, 75 percent of which are fired by oil ${ }^{18}$. Over several years, gas-based capacity will be increased due to the lower capital investments and shorter lead times compared with other fuel choices. By 2000, however, coalfired plants should account for more than $\mathbf{5 0}$ percent of generating capacity in the Philippines and Thailand, and almost a third in Indonesia. Coal is not expected to increase over current levels in Malaysia, as the government does not have plans to expand coal-fired capacity ${ }^{19}$. Renewable energy will also gain prominence. Hydropower will be developed in Indonesia, Thailand and the Philippines, while geothermal power will make up 20 percent of the Philippines' generating capacity by 2000 .

DOE recently estimated that the market potential for clean coal technologies in the Developing Pacific Rim is approximately 8,000 MW for retrofit applications, and ranges between 31,000 MW and 38,000

\footnotetext{
16 Ibid note 16.

19 Mohd. Annas, "Coal in Malaysia: Prospects for Future Demand", Proceedings of Conference on Coal. the Environment, and Development: Technologies to Reduce Greenhouse Gases, Australia, November 18-21, 1991.
} 
MW for new applications ${ }^{20}$ under low-growth and high-growth scenarios respectively. Base case projections for new app'ications were $34,300 \mathrm{MW}$.

This region is also reacting to environmental problems caused by the rapid growth in the industrial and energy sectors. Currently, coal-fired power plants in many countries have inadequate pollution controls, and have contributed to air pollution in their local areas. Clean coal technologies are not yet widely used. Some plants have electrostatic precipitators to control particulate matter, but few have any controls for sulfur dioxide and nitrogen oxides. This could change, however, as increasing environmental concerns provide governments with incentives to consider advanced technologies. These technologies would enable these countries to achieve both their environmental and power expansion goals. Unlike some other regions that rely on coal, ASEAN countries are more able to afford the use of clean coal technologies and are interested in advanced technologies that will reduce power-related pollution for retrofitting existing power plants and new applications. Planned generating capacity additions and the potential for clean coal technologies are discussed in each of the country profiles that follow.

Indonesia. The government is aggressively promoting development and use of domestic coal resources. The share of energy capacity held by coal-fired plants increased from 0 to 22.5 percent between 1984 and 1989 and should increase to 25.2 percent by 1994 , and 32 percent by $2000^{21}$. In 1991, total installed generating capacity was $19,000 \mathrm{MW}$. The Indonesian power utility, Perusahaan Umum Listrik Negara (PLN), owned and operated 12,000 MW and non-utility captive power generators added 7,400 MW more. Electricity demand is growing by 17 percent annually and peak demand on Java is expected to reach $21,000 \mathrm{MW}$ by $2000 .^{22}$ While most of the power needs are on Java, most of the resources are on other islands. Perusahaan Umum Listrik Negara plans to add 23,000 to 24,000 MW of capacity between 1990 and 2000 , most of which will be open-cycle combustion turbines and coal-fired capacity ${ }^{23}$. Up to $28,000 \mathrm{MW}$ could be added in the next decade, much of which the utility hopes to finance from internal operating cash flow ${ }^{24}$.

Potential for Clean Coal Technology. Indonesia has no plans to retrofit existing plants which fire lowsulfur coul (less than 1 percent) with flue gas desulfurization systems because emissions are below current limits. New coal plants designed to fire this low-sulfur coal may not require sulfur dioxide controls either. Indonesia has shown interest in dual-fuel plants (gas/coal), fluidized bed combustion units and

\footnotetext{
w U.S. Department of Energy, Market Potential for Clean Coal Technology Exports - Updated Estimates, Working Reper, October 1993.

${ }^{21}$ Asian Development Bank, Electric Utilities Data Book for Asia and the Pacific Region, Manila, January, 1993.

22Private Power Executive, "Southeast Asia-The Future is Now", July/August 1993.

${ }^{20}$ Private Power Executive, "Southeast Asia-The Future is Now", July/August 1993.

"Independent Eneray, "Double-Digit Growth", September 1993.
} 
integrated gasification combined cycle technology and plans to intensify research and collaborative efforts with Japan and the United States.

Thrlland. Thailand is planning to increase its current generating capacity of approximately 7,000 MW to $25,000 \mathrm{MW}$ by the year 2006 . Projections show that capacity will reach $13,000 \mathrm{MW}$ by $1996,19,000$ MW by 2001 , and between 22,000 and $25,500 \mathrm{MW}$ by 2006 . Ahout $20,000 \mathrm{MW}$ could be added in the next 10 years ${ }^{25}$. Fifty-nine percent of the new projects will be coal-fired, 20 percent gas, 8 percent hydro and 11 percent nuclear. Coal supplies for use in the power sector are obtained from both domestic and imported sources. Around 12 million tons of coal will be imported in 1996 for use in coal-fired plants totalling 4,200 MW.

Potential for Clean Coal Technology. Environmental problems attributable to coal-fired power plants are prompting the government to retrofit existing units with emissions controls and to design new facilities with advanced power generation technologies. Severe power-related pollution at the lignite-fired facility at Mae Moh has affected the health of the people in the surrounding communities. Residents of nearby villages have suffered respiratory illnesses caused by high sulfur dioxide emissions from this plant. The government is extremely conscious of these environmental problems and has promised to install additional air monitoring equipment and wet scrubbers in four of the eleven units - at a cost of $\$ 460$ million; wet scrubbers will also be used on the 10 additional plants to be constructed by 2006 . Future coal units will have pollution control equipment. Thailand is also considering fluidized bed combustion units to make economic use of extensive reserves of low-grade lignite. Currently, Thailand's pulverized coal units frequently experience slagging and fouling problems.

Malarsia Total installed capacity in 1992 was 6,645 MW. With continued strong economic growth, generating capacity is expected to increase 6.4 percent between 1990 and 1995 , and 7.2 percent from 1995 to 2000. Forecasts show between 18,000 and $23,000 \mathrm{MW}$ of new capacity will be on-line by $2020^{20}$, with almost $8,000 \mathrm{MW}$ to be added by $2000^{27}$. New capacity will be 35 percent combined cycle, 29 percent combustion turbines, 20 percent fossil-fired boilers and 16 percent hydroelectric.

Potential for Clean Coal Technology. Malaysia offers limited short-term opportunity for U.S. clean coal technologies. In 1990, Malaysia had two $300 \mathrm{MW}$ coal-fired units with triple-fuel firing capability (coal, gas and oil). Malaysia has no short-term plans to build more coal-fired capacity ${ }^{23}$. Natural gas is expected to play a major role in future power-sector expansion plans.

\footnotetext{
25 lbid note 22.

Whid note 16.

27 U.S. Agency for International Development, Office of Intermational Development, ASEAN Electric Power Generation Markets: Opportunities for U.S. Companies, Washington D.C., September 1992.

Ibid, note 5 .
} 
Phillonines. To alleviate acute electricity shortages, the government has made power sector development a top priority. Short-term measures include use of barge-mounted power units, but in the long-term coal and geothermal power will be developed. By 2000, geothermal power is expected to constitute one-fifth of total generating capacity. The state-owned National Power Corporation plans to add approximately 1,600 MW of new capacity between 1992 and 1996, consisting of $595 \mathrm{MW}$ of geothermal power, 520 MW of combined cycles, $300 \mathrm{MW}$ of fossil-fired boilers, $166 \mathrm{MW}$ of diesel-fired capacity and $80 \mathrm{MW}$ of hydropower. The fuel mix of planned capacity expansion between 1997 and 2000 is quite different: $1,250 \mathrm{MW}$ will be fossil-fired steam boilers, 1,000 MW will be geothermal power, $268 \mathrm{MW}$ hydropower, and $6 \mathrm{MW}$ in diesel-fired capacity 20 . Overall, the government hopes to add at least 20,000 MW over the next ten years, and has laid the groundwork for private sector participation. As an indication of the role private power will play, 66 percent of the $\$ 35$ billion in capital investments required in the 1993-2005 National Power Development Plan is expected to be provided by the private sector.

Potential for Clean Coal Technology. The Philippines is considering including low NO burners in new coal-fired plants, but it is unclear whether sulfur dioxide control equipment will be required. Currently, power plants can comply with sulfur dioxide emissions standards without installing control equipment. Increasing the height of the stack is a permissible strategy for sulfur dioxide controls because, officials argue, flue gas desulfurization equipment increases capital costs of construction by 20 to 40 percent ${ }^{30}$. Many of the gas-fired combined cycle plants currently being installed throughout the region could also be converted into integrated gasification combined cycle units if the comparative economics of the two fuels change. The modularity of combined cycle technology, initially burning gas, allows for coal to be added as a second fuel source at a later date.

Yietnam. In January 1993 installed capacity totalled about 3,000 MW, but it is unevenly distributed. There is a power surplus in the north and a deficit in the south. A north-south transmission line is being built to even out the distribution ${ }^{31}$. Demand for electric power is growing by 15 to 20 percent annually and by 2000 , southern Vietnam will have a power deficit of at least $1,000 \mathrm{MW}$ annually. At least 5,000 MW of new capacity, together with significant investment in transmission and distribution facilities, are needed between now and 2000 to keep up with demand ${ }^{32}$. Existing electric generating capacity consists of thermal power plants and hydropower. In 1988, thermal power plants accounted for 934 MW of

29 Ibid note 26.

${ }^{30}$ Dr. G.A. Bantugan, "Coal, Energy and the Environment: Philippine Setting", Proceedings of Conference on Coal and the Environment:Asia 2010, Honolulu, Hawaii, July 11-12, 1991.

"II Independent Power Report, "Vietnam Considering Private Power on a BOT Basis; Restructuring Utilities", January 29, 1993.

32 Independent Power Report, End of Vietnam Trade Embareo could open 57.7 Billion Development Market, pg. 9 , February 11, 1994. 
installed capacity, and of that $\mathbf{7 6 . 5}$ percent were coal-fired plants ${ }^{33}$. Average annual coal output from 1985 to 1990 was 6 to 8 million tons, about 2.4 million tons of which was used for power generation. The government is currently considering development of additional hydropower capacity in the north and central regions, and rehabilitation or expansion of a combined cycle plant in the south. More than 2,000 hydropower stations, ranging from $2 \mathrm{MW}$ to $100 \mathrm{MW}$ are to be built by 2000 .

Potential for Clean Coal Technology. Vietnam's needs for clean coal technologies, either for retrofit or new applications, are currently difficult to assess. While coal is used for power generation, hydropowei provides a significant share of total electricity supplies and accounted for more than 60 percent in 1991. With the lifting of the trade embargo it will be easier to obtain a more accurate assessment of Vietnam's potential power market.

South Korea. This country has a diversified electric generation portfolio. In 1991, coal provided 17 percent of total electricity supplies and oil provided 26 percent, while nuclear power, gas and hydropower provided 46 percent, 8 percent and 4 percent respectively.

South Korea is planning to develop a wide spectrum of technology and fuel choices. Installat generating capacity will triple from $21,021 \mathrm{MW}$ to $68,000 \mathrm{MW}$ in 20 years. Nuclear and coal plants will supply most of the base load, while gas and oil plants will be operated for peaking service. Nineteen nuclear plants and 35 bituminous coal plants are to be constructed ${ }^{34}$, an indication of the future role of nuclear power in meeting the base load electricity needs. Over the long term, 40 percent of the capacity is expected to be nuclear power. Other long-term targets of capacity portfolio by fuel type are: 30 percent coal, 20 percent oil and LNG and 10 percent hydropower ${ }^{35}$. With public opposition to nuclear power increasing, it is uncertain whether all these plants will be built. Several may be substituted with coal-fired plants if opposition increases.

Domestic coal reserves consist of anthracite that are used in residential and commercial sectors in the form of briquettes, replacing firewood. Coal consumed in the power sector is imported. Approximately 29 percent of the 22.8 million tons of bituminous coal imported in 1990 was used in the power sector. Power sector coal demand is expected to increase 9 percent annually between 1995 and 2010.

Potential for Clean Coal Technology. South Korea is phasing in emissions limits for sulfur dioxide and nitrogen oxide between 1991 and 1999 that will result in wider use of clean coal technologies. Sulfur

\footnotetext{
${ }^{33}$ Ngoc Anh Vien, "Coal's Use and its Effects on the Environment in Vietnam", Proceedings of Conference on Coal, the Environment, and Development: Technologies to Reduce Greenhouse Gas Emissions, Australia, November 18 - 21, 1991.

${ }^{34}$ H. Lee et. al., "Is the Future of Coal in Korea Promising or Dismal?", Proceedings on Conference on Coal, the Environment, and Development: Technolopies to Reduce Greenhouse Gas Emissions, Australia, November 18-21, 1991.

3s J. Gon Kim, "Coal Use Plans for Rep. of Korea: 1991-2006", Proceedings on Conference on Coal and the Environment: Asia 2010, Hawaii, USA, July 11-12, 1991.
} 
dioxide limits will be reduced from 700 to 270 parts per million between 1991 and 1999, with limits targeted at $500 \mathrm{ppm}$ in 1995 . These emissions standards apply to new and existing facilities. Most existing coal-fired units have electrostatic precipitators to control particulate matter, and low- $\mathrm{NO}_{\mathbf{x}}$ burners. Few have any sulfur dioxide controls, however. Currently, fuel switching to low-sulfur coal is being used to comply with the new standards, but as the standard becamas more stringent flue gas desulfurization units will be installed. All plants built after 1991 are designed with sulfur dioxide controls. Other policies to control energy-related pollution include expansion of gas use in urban areas and increasing the portion of low-sulfur diesel and unleaded gasoline to 100 percent.

Triwn. This country also has a diversified generation technology and fuel portfolio. Approximately 53.5 percent of currently-installed capacity is thermal, 31 percent is nuclear power and 15.5 percent is hydropower. In 1991, 91 percent (approximately 85,000 Gigawatt hours) of electric supplies were provided by coal ( 27 percent), oil (26 percent) and nuclear power (38 percent) combined. Due to unreliability of oil supplies and public opposition to nuclear power, future electric power supply will be largely provided by coal- and gas-fired plants, although two $100 \mathrm{MW}$ nuclear units have been proposed. Projections indicate that maximum demand will range from 25,632 to $30,800 \mathrm{MW}$ by 2000 .

Sixty percent of total coal reserves are exploitable. Coal production peaked in the 1960 s at 6.1 million short tons and has declined ever since. The decline is attributable to the high costs of mining, competition of cheaper imported coals and poor management. Forecasts indicate domestic production will fall to 110 thousand short tons by 2000 , while imports will continue to increase.

Potential for Clean Coal Technology. Taiwan's power sector regulations are structured such that increasingly stringent standards are phased in over a period of time. Under the new regulations, air emissions limits for sulfur dioxide and nitrogen oxide became progressively stricter between 1990 and 1993. It is unclear whether these limits also apply to existing units. Retrofitting existing units with sulfur dioxide, nitrogen oxide and particulate matter control systems is, however, being considered. New facilities will be required to comply with the new regulations, and much of the future coal-fired capacity could be designed with clean coal technologies.

\section{South Asin}

India is a major potential market for U.S. clean coal technologies due to its extensive use of coal to satisfy national energy needs. Pakistan, to a much lesser extent, could also be a market if government expansion plans are successful. The demand for electricity in both countries has risen significantly since the 1980s, and is expected to continue increasing throughout the rest of the decade. The growth is occurring primarily in the industrial sector, and analysts forecast that relatively steady economic growth will continue in the region ${ }^{36,37}$. Despite significant increases in total installed capacity during the last

\footnotetext{
3 Dr. R.K.Iyengar, "Innovative Technology Needs and Options for Power Generation in India", Proceedings of the Conference on Conl the Environment. and Development: Technologies to Reduce Greenhouse Gas Emissions, Australia, November 18-21, 1991.
} 
decade, the gap between electricity supply and demand continues to increase. The resulting shortfall has had a negative impact on industrial output and economic growth. India's economy grew at an average annual rate of 5.6 percent during the second half of the 1980s, but fell to 2 percent between 1991 and 1992 due to increased costs of imports caused by a simultaneous increase in oil prices resulting from the Gulf War, and a drop in dollar remittances from overseas workers. The demand for electricity, however, grew at annual average rate of 9.4 percent between 1987 and 1991, and is expected to grow at more than 8 percent a year through $1997^{30}$. Despite increasing installed generating capacity by 129 percent between 1981 and 1992 from 30,316 MW to $69,352 \mathrm{MW}$, India continues to experience severe power shortages. Projections show that by 2005 , capacity requirements will increase at least 100 percent and range between $139,000 \mathrm{MW}$ and $188,000 \mathrm{MW}^{39}$. Analysts indicate that, even if installed capacity increased to 153,000 MW by 2002 , there would still be a 12 percent shortfall in meeting peaking demand ${ }^{40}$.

The situation is similar in Pakistan. Total installed capacity in 1992 was $9,372 \mathrm{MW}$, consisting of a mix of thermal plants and hydropower. During the high-water months (July to November) there is no difficulty meeting the power demand. Insufficient reserves exist, however, to make up the power shortfall during the low-water months when hydropower generating capability falls. Load shedding (as much as 1,000 to $1,500 \mathrm{MW}$ ) is common during this period and has a profound impact on the economy. Estimates show that each kilowatt hour shed from the industrial sector results in a loss of 50 to 60 US cents to the national economy ${ }^{41}$. To make up the shortfall, forecasts indicate that 1,300 to $1,400 \mathrm{MW}$ of additional capacity is needed per year ${ }^{42}$.

To ease these acute power shortages, both governments are concentrating on bringing new capacity online as quickly as possible. Most of the planned capacity includes hydropower and thermal (coal, gas, and oil) power plants. Fuel diversification is becoming more important in Pakistan, where building of more gas- and oil-fired capacity in the short term, and more coal-fired capacity in the long term is planned to reduce its reliance on hydropower. Multilateral development banks and both governments are able to finance all the projected expansion. Therefore, India and Pakistan are seeking funding from

\footnotetext{
${ }^{37}$ D.J.Walls, D.E. Kleinschmidt, "Future Power Generation Technology Choices in Asia", Proceedings of the PowerGen Conference, Dallas, TX, November 1993.

37 Independent Energy, "Double-Digit Growth", September 1993

${ }^{39}$ K.K. Misra, "Coals future in Meeting Energy Demand in India", Proceedings of International Conference on Coal, the Environment, and Development: Technologies to Reduce Greenhouse Emissions, Sydney, Australia, November 18-21, 1991.

${ }^{\infty}$ K. Sridhar, A. Terway, "Coal Use for Power Generation in India", Proceedings of Conference on Coal, the Environment and Development: Technologies to Reduce Greenhouse Emissions", Sydney, Australia, November 1991.

4 G.M. Ilias, "Coal, Answer to Pakistan's Power Needs", Proceedings of Conference on Coal, the Environment and Development: Technologies to Reduce Greenhouse Gases, Sydney, Australia, November 18-21, 1993.

Power in Asia, February 1, 1993, 118/4
} 
domestic and international capital markets, by opening their power sectors to private participation. These countries are offering several projects to independent power producers.

A recent market-potential study conducted by DOE concluded that between $66,400 \mathrm{MW}$ and $81,100 \mathrm{MW}$ of new coal-fired capacity could be added in South Asia by $2010^{23}$. Most of these capacity additions are expected to occur in India due to its extensive use of coal. Approximately 46,000 MW of existing capacity could be retrofitted with clean coal technologies by 2010.

Power-related pollution and environmental degradation is severe in parts of India. An example is India's Singrauli region, which is rich in coal reserves. The abundant resources led to rapid development and industrialization at a cost to the environment. Local environmental problems are attributable to poor mining practices and a lack of pollution control equipment on mine-mouth power plants. Dust is a severe problem, caused mainly by loading, transportation and soil erosion that follows coal mining. Annual emissions of pollutants from the power plants are: 0.21 million tons of sulfur dioxide, 0.22 million tons of nitrogen oxides, 6.15 million tons of particulate matter, and 6,000 tons of carbon dioxide. Approximately 6 million tons of fly ash need to be disposed of annually. The Rihand reservoir is polluted with fly ash and mining sediments. Groundwater contains high concentrations of iron and chlorine. Forests and agricultural lands are being lost to industrial and residential development, while the local population is being displaced ${ }^{4}$.

Clean coal technologies are not yet widely utilized. They could, however, play a major role in preventing similar scenarios in other parts of India and Pakistan, where coal-based power generation is expected to increase in the future. India and Pakistan have expressed interest in advanced technologies, mostly for new electric power stations and industrial applications. Due to financial constraints, few existing power plants are expected to be retrofitted with pollution control equipment. Environmental concerns, however, will be integrated into future capacity planning. More importance is being given to preventing or reducing the environmental impact of future electricity production.

India. Coal is the primary energy source for power production, providing approximately 71 percent (220,486 gigawatt hours) of total domestic electricity in 1991. Sixty percent of total coal production is used in the power sector. In 1990 , roughly 69 percent $(48,000 \mathrm{MW})$ of total installed capacity was thermal ${ }^{45}$, and more than 86 percent of that thermal capacity was coal-fired. Although new oil and gas plants are planned, coal will remain the dominant fuel for power generation in the future. Indian analysts forecast that total capacity additions by 2005 will be between $69,648 \mathrm{MW}$ and 118,648 MW. Based on

\footnotetext{
4.S. Department of Energy, Office of Fossil Energy, "Market Potential for Clean Coal Technology Exports Updated Estimates, Working Paper", Washington D.C., October 1, 1993.

4 Asian Development Bank, Integrated Energy-Environmental Planning, Manila, May 1992.

${ }^{45}$ Ibid note 45.
} 
historical development patterns and reliance of coal for power generation, a significant portion is expected to be coal-based capacity.

Recoverable reserves of coal are estimated at 68,928 million short tons ${ }^{46}$. Large portions of reserves, however, are low quality non-coking coals. Typical coals have energy contents between 6,000 and 8,000 Btu/lb, ash content of 26 to 32 percent $^{47}$ and sulfur content between 0.2 and 0.5 percent by weight ${ }^{48}$.

Power sector coal consumption is expected to continue increasing to meet demand. Approximately 122 million short tons of coal were used in 1988-89, 143 million in 1991-92, and estimates for 1992-93 indicate an increase to approximately 165 million short tons ${ }^{40}$. Despite these increases, domestic demand continues to exceed production. The resulting shortages are further worsened by transportation problems between the coal fields in the southeast and the major demand centers throughout the country. In 1991, 67 percent of all produced coal was transported by rail. The railway system is under strain and operating at capacity saturation levels. Large capital investments will be required for upgrades.

Potential for Clean Coal Technology. India is interested in a variety of clean coal technologies for power generation and coal beneficiation. The government is interested in fluidized bed combustion because it is suitabie for firing indigenous low-grade coals and lignite for power generation. India has conducted demonstrations of this technology and is interested in developing full-scale utility units. Fluidized bed combustion units are now widely used in India for industrial boilers ${ }^{\mathbf{s}}$. It is unclear whether existing units are equipped with emissions control.

India is also considering integrated gasification combined cycle for power generation because of the high efficiency compared with other technologies. Demonstrations have been conducted together with international organizations such as the U.S. Agency for International Development.

\footnotetext{
4 U.S. Department of Energy, Energy Information Administration, Intermational Enerey Annual 1991, DOE/EIA0219(91), Washington D.C., 1992.

7 World Bank, Steam Coal for Power and Industry. Issues and Scenarios, Washington D.C., October 1992.

- K. Sridhar, A. Terway, "Coal Use for Power Generation in India", Proceedings of Conference on Coal, the Environment and Development: Technologies to Reduce Greenhouse Emissions, Australia, November 1991.

- N.Ramji, "Regional Opportunities in Private Power - Republic of India", Proceedings of Conference on Private Sector Power in Aris, Kuala Lumpar, Malaysia, October 27-29, 1992.

50 Ibid note 55.
} 
India has also conducted studies on the benefits of using beneficiated coal at power plants. Some use of

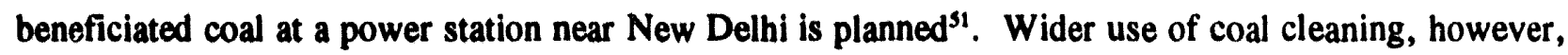
is constrained by a lack of capital to finance coal beneficiation facilities ${ }^{32}$.

Despite the existing level of interest for clean coal technologies, the real incentive to use these technologies widely will occur when environmental requirements for power sector operations become stringent enough to force their use. This is slowly occurring. Environmental regulations covering power plant emissions specify ambient air quality standards depending on the activity in the area. The most stringent standards are in parks or areas with historical sites, while the most permissive standards are in industrial areas. They specify limits for sulfur dioxide, nitrogen oxides, carbon monoxide and particulate matter. Air emissions standards for power plants, for example, specify limits for particulate matter based on the boiler size and stack height. These standards are less stringent than U.S. standards.

Pakistan. Although coal is a major energy resource in Pakistan (577 million short tons ${ }^{53}$ ), most coal fields remain undeveloped and coal currently plays only a minor role in meeting electricity demand. Less than 1 percent (0.07 percent or 35 gigawatt hours) of total power production in 1991 was coal-based. Power sector coal consumption remains virtually stagnant at relatively low levels. Although annual production of coal is between 2 and 3 million tons, only 30,000 to 40,000 tons are used in power generation; the majority is used for making bricks. This could change, as the Pakistani government implements plans to increase coal utilization in the power sector. The government is planning major expansion of coal-fired capacity after 1998 as part of a strategy to exploit undeveloped coal resources. Long-term policies have been implemented to increase industrial use of coal, including allowing local and foreign private companies to develop mines for power plant projects, and to increase use of coal in the power sector.

Potential for Clean Coal Technology. Pakistan offers limited opportunity for U.S. clean coal technology in the short term. This could change as long-term coal sector policies are implemented. The government is interested in and has conducted demonstrations of fluidized bed combustion because it is suitable for firing indigenous low-grade coals and lignite for power generation.

The government is also paying more attention to environmental fallout from power plant operations. Although no comprehensive body of environmental regulations covering power plant emissions exists yet, detailed environmental impact assessments must be conducted for every public and private power sector project. As a minimum, these assessments must address the direct and indirect impact of power projects

\footnotetext{
st Dr. R.K. Iyengar, "Innovative Technology Needs and Options for Power Generation in India", Proceedings of the Conference on Coal. The Environment. and Development: Technologies to Reduce Greenhouse Gas Emissions, Sydney, australia, November $18-21,1991$.

52 Ibid note 55.

s3 U.S. Department of Energy, Energy Information Aúministration, International Eneray Annual 1991, DOE/EIA0219(91), Washington D.C., 1992.
} 
(during construction and operations) on the environment and local communities, including the impact of resettling populations displaced by such projects. Air dispersion modeling of power plant emissions is required, using at least one year of pre-operations baseline meteorological data. The impact of discharged water on local water quality must also be conducted. These studies have caused proposed projects to be stalled or redesigned. These environmental regulations should provide strong incentives for clean coal technologies to be used as coal use for power generation increases.

\section{TRANSITIONAL ECONOMIES}

Central Europe and the Newly Independent States (NIS), especially Russia, Ukraine and Kazakhstan, will be major markets for clean coal technologies for either retrofits to, or replacements of, existing coal generation capacity. The NIS are the world's third largest coal consumers, using 744 million short tons in $1990 . .^{.4}$ Ninety-four percent of this total was consumed in Russia (60 percent), Ukraine (23 percent) and Kazakhstan (11 percent). These three republics also produced 98 percent of the Soviet Union's coal in that year. Most of the coal used in the NIS is mined in these three republics. Poland and the Czech Republic are major coal producers in Central Europe, and use coal for more than 75 percent of their electricity production. Many of the facilities in which coal is burned are in poor condition and have no environmental controls.

Turbulent economic and political conditions in Central Europe and the NIS have reduced energy and electricity consumption dramatically since 1989. This corresponds to an overall reduction in economic activity as these economies are being restructured. The decline in electric consumption reflects the declining output of highly inefficient energy-intensive industries that consumed much of the electricity produced. For example, between 1989 and 1992 electric consumption declined 15.4 percent in Poland, 15.2 percent in Hungary and nearly 30 percent in Romania. ${ }^{35}$ In Ukraine, consumption in the most electric-intensive sectors began to drop in 1990, and has continued to decline at an accelerated pace, for a total of $\mathbf{1 5 . 6}$ percent between 1990 and 1993. Electricity demand throughout Central Europe and the NIS will probably continue to decline as political and economic reforms continue.

\footnotetext{
34 Eneray Information Administration, International Energy, October 1992.

is U.S. Department of Energy, Electric Power Technologies, U.S.-Central Europe-Former Soviet Union, Proceedings, September 1990
} 


\section{Planned Generatine Capacity Additions}

As a result, utilities throughout the region are concentrating on rehabilitating and replacing older fossil and nuclear power plants rather than building new power plants to meet load growth. Growth in electric demand may resume, but it is not clear when and at what rate. Most guesses are after the turn of the century. DOE estimates that between $79,000 \mathrm{MW}$ and $81,000 \mathrm{MW}$ of existing capacity in Central Europe could be retrofitted with clean coal technologies by 2010. Similar retrofit estimates for the NIS range from $94,000 \mathrm{MW}$ to $96,000 \mathrm{MW}$ of existing capacity. Approximately 1,312 MW of new capacity using clean coal technologies could be built in Central Europe by 2010, while between 11,300 MW and $25,110 \mathrm{MW}$ of new clean coal technology capacity could be brought on-line in the NIS ${ }^{5}$. There are questions, though, as to whether these countries will be able to finance the high investment required for clean coal technologies without assistance from international sources.

Much of the electric generation takes place in combined heat and power plants that provide thermal energy for district heating or industrial cogeneration. District heating use makes these often illmaintained plants even more critical during the cold winters. The plants are located in highly populated areas where their uncontrolled emissions affect large numbers of people. District heating is also often highly inefficient, with steam production and usage seldom metered and steam losses heavy throughout the system.

Approximately $\mathbf{4 5}$ percent of global coal resources are located in the countries of the Former Soviet Union. The coal industry, while extensive in Central Europe and the NIS, is inefficient and has suffered greatly from uneconomical management during the communist era. Extensive effort is required to rationalize the industry including the institution of market-based pricing for coal, the application of modern management and mining techniques and the closure of uneconomical mines. Plans for general economic reform rationalization of the coal industry are under way to various extents in each country. This will cause suffering on the part of miners, whose level of living has declined and who may be thrown out of work. This can result in political turmoil in countries where miners are a significant political force.

Central Europe. Coal is produced in every country except Slovakia, which obtains most of its supply from its former political partner, the Czech Republic. Hungary and Bulgaria, with limited coal reserves of their own, import some of the coal they consume from other former Eastern Bloc countries. Although the situation varies by country, coal is the predominant energy source for power generation, accounting for nearly two-thirds of the electricity generated..$^{37}$ This dominance is due to its domestic abundance in most countries. Coal is the only fuel in which some countries approach self-sufficiency, a fact that takes

\footnotetext{
56 U.S. Department of Energy, Market Potential for Clean Coll Technology Exports, Updated Estimates, Working Paper, October 1, 1993.

57 International Energy Agency, Energy Statistics and Balances of non-OECD Countries, 1991 Paris, 1992
} 
on added importance in an era when imports must be paid for in hard currency at market prices. With the exception of Albania, at least 30 percent of total electricity production was coal-based in 1991. In the Czech Republic and Poland, coal accounted for 76 percent and 95 percent of total power production in 1991 respectively. Most of the coal-fired power plants in the region are relatively old (built between the 1950s and 1970s), inefficient and have few environmental controls. The primary concern when these plants were built was to maximize production, not control environmental residuals. Many have been very poorly maintained and have degraded over the years.

The Newily Independent_States. Coal is an important fuel source in the former Soviet Union. Total consumption for power generation varies by country. In 1990, coal accounted for one-third of the power generation in the Former Soviet Union"s, with 52 percent of total coal consumption going to electricity production. By 1992, however, coal's share in fuel consumption for electric power generation had fallen to about 18 percent from 30 percent in 1990. In 1992, coal accounted for 15 percent of total power production in Ukraine, 18 percent in Russia, and 80 percent in Kazakhstan. Russian officials indicate that coal's share in fuel consumption could increase to 43 percent in $2010^{59}$, by which time the fuel supply situation in Russia should have normalized. The use of gas for power generation will be reduced from current levels, while coal capacity will be expanded to take over the supply.

This decline is caused in part by a fuel shortage crisis in Russia, Ukraine and Kazakhstan resulting from serious shortages of equipment and supplies, miner strikes, the cumulative effects of the disruption of old supply channels and the slow pace of creating new economic institutions. In Russia, the world's fourthlargest coal producer, production has fallen steadily since 1988, and was below 1970 levels in the first half of 1993. Coal production in Ukraine has declined by 30 percent since the mid-1970s, representing the biggest factor in Ukraine's overall decline in energy production since the 1970s. Production declined by 17 percent in 1991, when a month-long industry strike accounted for half the decline, but was slowed to 3 percent in 1992. Kazakhstan was the third-highest coal producer of the Soviet Republics in 1990. Output has declined steadily since peaking at 143.1 million tons in $1988^{50}$. In 1992, production reached 125 million tons, a decline of nearly 13 percent.

\section{Rotential for Clean Coal Technologies}

The potential for clean coal technologies is significant. In the short term, retrofits/refurbishment of existing plants with emissions controls provides the most opportunity for U.S. clean coal technologies. Over the long term, as the demand for power increases again, opportunities for U.S. clean coal technologies could shift towards new applications.

\footnotetext{
* Private Power Bxecutive, May/June 1993.

50 Central European Eneray, "Russian Minister Sees Coal as Main Fuel for Power Sector", EEE 6/4, March 1992.

* International Energy Agency, Col Information 1992, IRA Statiatice 1992, Paris 1993.
} 
Until the recent political changes in these countries, virtually no priority was placed on environmental concerns. Environmental problems were often ignored in order to build infrastructure as quickly and cheaply as possible. Strict laws that promoted environmental standards were also ignored.

Uncontrolled combustion of low-quality coal in power plants and other facilities has caused extensive environmental degradation and health problems throughout the region, including not only poor air quality, but also water pollution, acid rain damage, and land contamination from radiation and toxic waste. Adding in the large land area converted to hydroelectric production, it is estimated that up to one-sixth of the productive land in the Former Soviet Union has been negatively impacted by power production. Air toxics released from the combustion of low-grade coal accumulate in the soil and contaminate food. Particulate emissions are high in some areas-Poland, for example. Sulfur dioxide emissions and loadings from high-sulfur lignite are high, especially in Poland, the Czech Republic, and Slovakia. In some areas of the former Czechoslovakia, for example, bone growth in children is retarded by 10 months or more. ${ }^{61}$

Political reaction to these environmental pressures has varied by country. The priority of environmental concerns must be ranked against the many pressing economic and social needs of each country. The development of strict environmental regulations and the real threat of enforcement would provide incentives for countries to clean up power plant operations. Under these conditions, clean coal technologies could play a significant role in mitigating the environmental fallout of continued coal use for power generation.

Central Europe. Newly-elected governments have afforded environmental issues top consideration and efforts are being made to prevent future environmental degradation. Although the situation varies by country, most countries have adopted energy policies that effect the requirements for clean coal technologies. These include improved efficiency on the supply and demand side in order to reduce demand for coal; reducing the environmental impacts of firing coal in the power and industrial sectors, and for district and home heating; and diversifying fuel supplies away from coal to natural gas ${ }^{62}$, and away from imports of electricity and all fossil fuels from the former Soviet Union to domestic and western sources.

Clean coal technologies of most interest include fluidized bed combustion and integrated gasification combined cycle for repowering and replacement installations and sulfur dioxide, nitrogen oxides and particulate controls for retrofits. Coal cleaning is also important to reduce particulate emissions, especially from smaller-scale applications. Governments and utilities in the region have ambitious plans to add environmental controls to coal-fired power plants and are seeking or receiving foreign funding to do some of it.

\footnotetext{
${ }^{61}$ Chandler, W.W., Makarov, A.A, Dadi Z., "Energy Uses for The Soviet Union, Central Europe, and China", Seientific American, Volume 263, No 3., September, 1990.

Q Central European Enerey, EEE 8/4, May 1992.
} 
Poland has experienced severe environmental degradation due to uncontrolled burning of brown coal for power plants, industry and home heating. Indeed, coal accounts for more than 90 percent of energy consumption. Poland has embarked on a major program of electric power industry restructuring that includes privatization and the rehabilitation of power plants. The goal is both to modernize the electric power systems, reduce pollution, extend lifetimes and increase efficiency. Polish officials estimate that 4,000 MW of coal fuel capacity will be retrofitted with pollution controls in the 1990s, and 8,600 MW will be retrofitted in the following decade. Poland is also considering circulating fluidized bed combustion for new power plants.

The Czech Republic has many severe environmental problems, some of which are caused by coal combustion. Coal use for electricity production is responsible for the largest share of all air pollution. All but two of the top 25 sulfur dioxide emitters in the former Czechoslovakia are power plants in the Czech Republic. Most lignite-fired power plants in Northern Bohemia and Moravia create intense air pollution problems. They operate without controls for either sulfur dioxide or nitrogen oxide. All of these plants are subject to strict new emission limits set by the Czech Clean Air Act of 1991. Plants that do not meet these limits by 1998 will be taken out of operation. The Czech Republic anticipates spending U.S. $\$ 2$ billion between 1993 and 1997 for retrofitting and upgrading its power plants ${ }^{63}$. In March 1993, the government approved the completion of the $2000 \mathrm{MW}$ Temelin nuclear power plant, in part to reduce the environmental impacts of coal combustion. Germany and Austria are opposed to the project. Austria even offered to provide free electricity if existing nuclear facilities are shut down $n^{64}$.

Slovakia has launched an extensive retrofitting program designed to reduce pollution from its coal-fired generating units, all of which burn high-sulfur lignite from the Czech Republic. The plan involves adding flue gas desulfurization and nitrogen oxide control to several coal-fired generating units, replacing others with fluid bed combustion or gas turbine cogeneration, and decommissioning other units. A total of 22 generating units with $1,971 \mathrm{MW}$ of generating capacity are affected, nearly 90 percent of the fossil generation total. The retrofit plan is expected to cost $\$ 690$ million and to be completed by 2000 .

Hungary constructed all of its coal-fired power plants in the 1950s and 1960s to burn either brown coal or lignite. Currently, no $\mathrm{SO}_{2}$ or $\mathrm{NO}_{x}$ controls are used, but Hungary is particularly interested in modern U.S. emissions control technologies developed to meet Clean Air Act Amendments ${ }^{65}$. Measures are being taken to retrofit existing power plants with flue gas desulfurization systems. The World Bank and other multilateral organizations are providing financial and technical assistance.

" Coal and Synfuels Technology, "East Europe Leaders Outline Energy Needs", Volume 14, No. 16, April 26, 1993.

a U.S. Senate, Committee on Eneray and Natural Resources, "Energy Profiles of Czechoslovakia, Hungary, and Poland, and their Emerging Market Economies, June 1991.

6s Central European Energy, EEE 8/4, May 1992. 
Romania generates most of its power in older thermal power plants, many of which are in poor condition and burn low-quality fuels (high-sulfur lignite or oil) without environmental controls. Romania has started a program to rehabilitate four $330 \mathrm{MW}$ coal-fired generating units at two power stations. The priority is to restore these plants to operating condition. The availability of funds for environmental projects is a particularly acute problem in Romania due to its poor economic condition.

Bulgaria has six coal-fired power plants with a total of 4,560 MW of generation capacity. Four of these plants $(2,900 \mathrm{MW})$ burn low-grade lignite coal from Maritza East, the only domestic energy resource. The other two units $(1,660 \mathrm{MW})$ burn imported coal from Ukraine. None of the units have any pollution control and some are reaching the physical limit of their operating life. Although Bulgarians are concerned about emissions from these plants, rehabilitation or replacement has a higher priority. The approximately $12,000 \mathrm{MW}$ of installed capacity in 1992 was in such poor condition that it could cover only 7,200 MW of actual load. A major regional elect ic power environmental/safety concern is the safety of the Kozuldoy nuclear power plant, which supplies more than 25 percent of the country's electric power. Even so, Bulgaria is considering expanding its nuclear capacity.

The Newly Independent States. Environmental considerations are now receiving greater attention than was previously the case. While strong public interest in environmental issues has emerged in recent years, political and economic instability has made it difficult to make environmental progress. There is both a lack of enforcement capability and a need to spend money on more critical items. Since 1988, the Russian government has promulgated new, innovative approaches to environmental management, but has not established enforcement structures capable of implementing them. The greatest strides in combatting pollution have actually been the imposition of rational pricing for fuels, electricity and goods and the contraction in the economies of these countries. A move to obtain greater efficiency in industrial and power sectors is also taking place. The faltering economies of the NIS make it unlikely that funds will be available for day-to-day management of environmental programs, monitoring or enforcement.

Some gradual progress has been made in the power sector by building higher smokestacks, shifting from high-sulfur oil and coal to natural gas and low-sulfur coal, and performing some basic particulate removal. All of these are low-cost options. Clean coal technologies are not widely used in the region, but could provide a marked reduction in power-related pollution if they were. As the NIS start integrating environmental considerations into power sector policies, they are showing greater interest in these technologies. It is uncertain how many existing plants will be retrofitted with control technologies. For example, in Ukraine many plants are past their closure or retrofitting deadlines and average only 25 30 percent efficiency. The shortage of funds and foreign exchange, makes it difficult to assess the extent to which CCT technologies will be utilized, especially during the current turbulent economic period. 
Russia. Russia is particularly interested in circulating fluidized-bed technology. The Russian government is considering "wide introduction of this technology for our coal-fired electric power generating plants, "66 and has agreed to a deal with a vendor of circulating fluidized-bed boiler systems.

Kazakhstan. High-ash coal supplies more than 75 percent of all fuel consumption, and 80 percent of total electricity production. The use of this coal in plants designed with outdated technology has caused severe maintenance and pollution problems. Some plants have been derated up to 25 percent. The government has identifi i major causes of power-related pollution including low efficiency of wet ash filters and electrostatic precipitators (below design efficiency), lack of modern coal cleaning/preparation technologies and lack of flue gas cleaning equipment to remove sulfur dioxides and nitrogen oxides.

Other Newly Independent States. Less coal is used in the other NIS countries, but there are substantial environmental problems where other fuels are used. For example, environmental issues are now in the forefront in Estonia because of pollution caused by oil shale-the primary energy source. Latvia uses high-sulfur fuel oil and has no capacity to remove the sulfur. Environmental control technologies -including clean coal technologies -- will be needed in these and other NIS countries.

\section{OTHER REGIONS}

Other regions of the world are also markets for U.S. exports of clean coal technologies. These include Latin America and Africa, especially the southern region. Opportunities in these regions, however, are less well defined than those in the Asia-Pacific region, Central Europe and the NIS.

\section{Latin Americas}

Several Latin American countries (Mexico, Brazil, Argentina, Peru, Chile and Colombia) have significant coal resources, but they are relatively unexplored. Argentina, Brazil, Chile, The Dominican Republic, and Mexico have existing coal-fired plants and, with the exception of Argentina, are planning to build new coal-fired plants. The time scale for all these plants is uncertain and it is possible that much of this capacity could be gas- or oil-fired given current low prices.

DOE projects that 4,000 MW of existing coal-fired capacity could be retrofit with clean coal technologies between 1993 and 2010. In addition, between $350 \mathrm{MW}$ and 2,200 MW of new coal-fired capacity could be built during the same period. All this capacity could potentially be designed with clean coal technologies ${ }^{67}$. Mexico and Brazil are potential markets for power generation technologies, and Peru is a potential market for coal preparation and beneficiation technologies. Mexico and Brazil are planning

"Coal \& Synfuels Technology, "East Europe Leaders Outline Energy Needs", Vol 14. No. 16, April 26, 1993

7 U.S. Department of Energy, Market Potential for Clean Coal Technology Exports, Updated Estimates, Working Paper, Washington DC, October 1, 1993. 
to increase coal's share in total capacity mix, however, coal will play a smaller role in meeting the electricity needs of these countries compared with other fossil fuels.

Mexico. Installed capacity totalled 29,204 MW in December 1993 and consisted mainly of fuel oil and hydropower, which together account for 87 percent of that total. Coal's share in total generation capacity mix was 6.5 percent. Growth in electricity sales averaged 3 to 4 percent between 1989 and 1991, and is expected to remain at least within this range over the next 10 years. Electricity forecasts developed by the Mexican Energy Commission for 1995 to 2000 show growth in power demand running at about 6 percent annually. At this rate, approximately $12,200 \mathrm{MW}$ of new capacity will be required by 2001 . In addition, the advancing age of existing capacity increases the likelihood that even more replacement capacity would be needed. Nearly 17 percent of existing capacity is more than 30 years old, 16 percent between 20 and 30 years old, and 43 percent between 10 and 20 years old.

The Mexican Energy Commission's original expansion plans identified a variety of generation technology choices and fuel options that would be developed. It also provided specific shares that each fuel would contribute to total capacity mix. However, these plans have been abandoned. The Mexican Energy Commission's current plans see the private sector developing a large portion of the $12,200 \mathrm{MW}$ of anticipated new capacity that will be required by 2001 . Under this new regime, independent power producers will select the fuel. Although the Mexican Energy Commission has an interest in increasing coal's share of final power mix as part of the diversification strategy, it cannot estimate how much coalfired capacity will be developed. To date, 1,400 MW of the total 12,200 MW is committed coal capacity. One $700 \mathrm{MW}$ facility is strictly coal, and two $350 \mathrm{MW}$ dual-fired units will be brought on-line in 1994 and 1995.

Potential for Clean Coal Technology. Mexico's current environmental regulations set emissions limits for the discharge of criteria pollutants into the air and water. In the energy sector, new regulations and policies that integrate environmental issues have been developed for the coal mining and beneficiation industries. Existing coal-fired power generating units burn beneficiated coal, and have electrostatic precipitators for particulate removal. These units are candidates for nitrogen oxide controls. Use of lowsulfur coal (<1 percent) reduces the need for sulfur dioxide controls, however, if air pollution regulations become more stringent, units will be retrofit with scrubbers. New coal-fired power plants may need to include emissions controls for sulfur dioxide, nitrogen oxides and particulates.

Brazil. Brazil obtains most of its electricity supplies from hydropower. Coal currently provides 2 percent of total power supplies. Development plans call for coal's share to double to 4 percent by 2010 . Currently coal-fired capacity totals $1,050 \mathrm{MW}$. The public utility ELECTROSUL is planning to increase coal-fired capacity to 7,150 MW by 2010; an increase of nearly 600 percent. Beyond 2010, capacity expansion plans show a shift from hydropower to coal. Most of Brazil's "easily exploitable" hydropower potential will be developed by then, making it increasingly difficult to rely on this source. The older hydropower stations (those approaching 30 years) will require substantial investment for maintenance and upkeep. The government is planning to exploit indigenous coal resources to replace these stations. 
Potential for Clean Coal Technology. Brazil's domestic coal reserves consist primarily of low-rank coals which are principally used for power generation and industrial heating. Currently, imported coal is used for metallurgic purposes. The Coal Commission's long-term plans, however, call for greater use of domestic coal reserves, which will require upgrading/beneficiation. The Environmental Commission recently enacted new environmental regulations applicable to the power sector. These new regulations are so stringent that indigenous coal cannot be fired without emissions controls. The Coal Commission is worried that these requirements will inhibit the use of domestic coal and is working with the Environmental Commission and environmental community to find solutions. The government is interested in all clean coal technologies. Atmospheric fluidized-bed combustion is one technology being explored for plants built after 2010. The Brazilian Government is interested in cooperating with private sector and foreign governments in clean coal technology development efforts for power sector projects.

\section{Arice}

In Africa, the southern region is the primary market for clean coal technologies. Most of Africa's reserves of coal are located within the Republic of South Africa and the member states of the South African Development Community (SADC) ${ }^{68}$, but a broad unexplored resource base exists throughout Africa. The Republic of South Africa has sizable coal deposits and an extensive coal technology base due to its years of economic isolation. Strong economic growth is anticipated with its rejoining the world community and South Africa is seeking collaborative efforts with other countries, including the United States. U.S. clean coal technologies may have to be adapted to the special characteristics of the South African coal (high ash melting temperature). Moreover, the surrounding SADC countries of Zimbabwe, Zambia, Botswana, Mozambique, Swaziland and others have significant coal deposits and are expected to participate in the economic growth sparked by the collective efforts of SADC and the reemergence of South Africa. Although the SADC was formed to promote regional cooperation by synchronizing development plans and reducing dependence on South Africa, post-apartheid South Africa is expected to become a member of the SADC, significantly increasing the regions common assets, resources and capabilities. Other opportunities may exist in Morocco, Algeria and Egypt in North Africa and Niger, Nigeria, Upper Volta, Mali and Sierra Leone in West Africa. Niger already has plans to expand coalfired capacity.

Planned Generating Capacity Additions. Increased demand for electricity is driven by economic growth and the desire to electrify Africa, especially Southern Africa. The SADC Member countries and South Africa are jointly pursuing electrification of Sub-Sahara Africa. Sub-Sahara Africa has about 150 million people, and only ten percent of this population is hooked up to the electric supply. Similar to Southern Africa, the entire continent is under-electrified. Within the SADC, economic growth varies significantly by country. For example, between the 1970 s and 1980s, Botswana's economy experienced

\footnotetext{
Member nations of the South African Development Community are Angola, Botswana, Lesotho, Malawi, Mozambique, Namibia, Swaziland, Tanzania, Zambia and Zimbabwe.
} 
rapid growth, primarily due to expansion in the mining sector. This growth was matched by an increase in energy consumption. While the mining sector (minerals and metals) is still the largest consumer of electricity, demand by industrial, commercial and domestic users continues to increase. In 1991, real growth rate was the highest for SADC countries, estimated at 6.3 percent. By contrast, Zambia's economy has been in decline for over a decade due to declining copper production and ineffective economic policies; in 1991, real Gross Domestic Product fell by 2 percent. Except for South Africa, the other SADC countries reported growth, although lower than Botswana's.

The potential for growth in electric demand is significant in all SADC countries and South Africa. To further substantiate the point, the domestic sector still has little electricity available to it. Rural areas, where most of the population lives, have large-scale shortages of commercial energy, assuring a continual pressure to increase electrification. For example, only 30 percent of households in towns in Botswana, and 5 percent of households in villages connected to the national power grid have electricity. Similar situations exist in other SADC countries. Forecasts for Botswana indicate that electricity consumption will grow by 6.1 percent annually between 1989 and 1997 . By 1995 the state-owned utility will have to either

TOTAL COAL RESERVES (Million Short Tons)

\begin{tabular}{|l|r|}
\hline \multicolumn{1}{|c|}{ Country } & \multicolumn{1}{|c|}{ Reserves } \\
\hline Angola & 3,857 \\
Botewana & na \\
Lesotho & na \\
Malawi & 264 \\
Mozambique & $n$ \\
Namibia & 209 \\
Nigeria & 60,977 \\
South Africa & 2,006 \\
Swaziland & 200 \\
Tanzania & 112 \\
Zambia & 809 \\
Zimbabwe & \\
\hline m-Not Avaliable & \\
SOURCES: World Bank, World Development Report, 1993, \\
Washington DC, 1993. \\
Energy Information Administration, International Energy \\
Annual 1991, DOE/EIA-0219(91), Washington DC, December \\
1992.
\end{tabular}

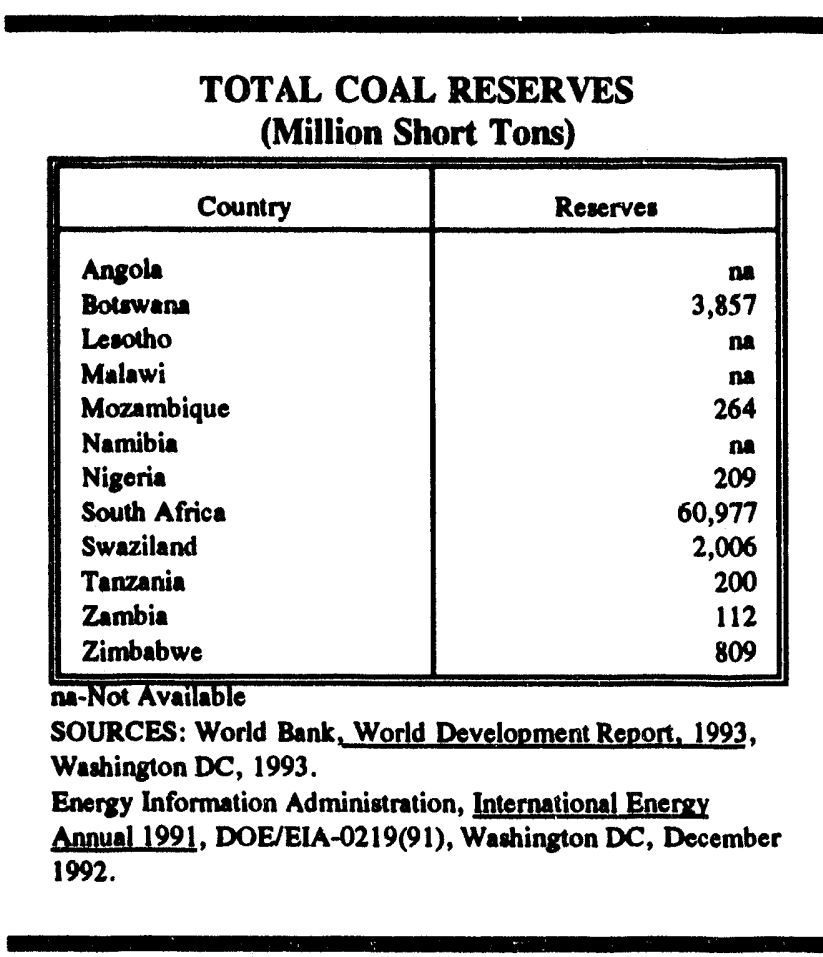
expand generating capacity, or enter into additional power supply agreements with neighboring countries (e.g Zimbabwe).

Most of SADC's rural and urban population relies on wood fuel to satisfy their energy needs. Increased use is leading to a vicious cycle of poverty. Scarcity and growing demand for supplies promotes deforestation, soil erosion and environmental degradation, each reinforcing the other in a downward economic/environmental spiral and lowering of living standards. Population growth rates of 2 percent in SADC countries (including South Africa) further heighten the need for more efficient, environmentallysound use of domestic and regional natural resources.

Increased demand for electricity could also occur in the mining sectors of countries that earn significant revenues from mineral and metal exports (e.g. Angola, Botswana, Namibia, and South Africa).

SADC countries and South Africa have abundant energy resources, including coal, oil, gas and hydropower resources. Energy development plans are designed to take advantage of each country's reserves and regional resources. A variety of power generating technologies and fuel options are available. While oil reserves are located in Angola, and gas reserves in Mozambique and South Africa, 
deposits of anthracite and bituminous coal are found in at least seven countries, increasing the probability that energy development throughout the region could, to a large extent, be coal-based. Most of the existing capacity in SADC countries is hydropower. Recent droughts, however, have reduced the output of these facilities. To improve system reliability and reduce reliance on hydropower, governments are concentrating on exploiting other regional fuel reserves, including coal for power generation.

A rough estimate is that approximately $28,000 \mathrm{MW}$ of coal-fired capacity currently exists in Africa. In addition, Significant amounts of new capacity could be added between 1993 and $2010^{69}$. All the existing capacity could be eligible for retrofit with clean coal technologies, while all the new capacity could potentially be clean coal technologies.

The Republic of South Africa currently has excess capacity, and exports power to neighboring states. Eskom, its largest utility, however, has plans to electrify 300,00 to 500,000 homes a year in South Africa, and is one of the leading utilities participating in the Sub-Sahara electrification planning. The Republic of South Africa can be expected to compete in the southern Africa market by virtue of its proximity and technology.

In North Africa, Morocco currently has two coal-fired plants with a total capacity of $465 \mathrm{MW}$, and plans to build a new 2-unit $600 \mathrm{MW}$ coal-fired plant with low $\mathrm{NO}_{\mathrm{x}}$ burners and electrostatic precipitators. Egypt plans a 1,200 MW coal-fired power plant with possible expansion to 2,400 MW. Niger (in West Africa) plans a $260 \mathrm{MW}$ hard coal-fired power plant ${ }^{\circ}$. There is some interest in coal deposits in Nigeria and other West African countries, but no plans for coal-fired power plants are currently known.

Potential for Clean Coal Technology. It is difficult to assess the potential for clean coal technology in Africa. DOE is currently performing a comprehensive evaluation of Africa's fossil energy and technological needs potential. With the exception of South Africa, Zimbabwe and Botswana, Africa's coal resources are not well explored. It is possible that additional sizable coal deposits will some day be exploited. The overall competitive position of the U.S. in Africa is weak. Discussions are currently underway between the SADC and German authorities to field an appraisal mission to the region to determine the extent and nature of German involvement in the regional coal program. Germany already provides technical assistance in the energy sector to several SADC countries. Other countries active in the region include Japan, Canada, Denmark and the Netherlands.

SADC countries are now giving greater consideration to environmental issues and are integrating these concerns into the energy sector. All energy projects within member states are required to comply with generally accepted environmental requirements of the region, including air and water emissions. In Botswana, the energy sector plays a major role in overall environmental policy. The government has

\footnotetext{
- U.S. Department of Energy, Marke Potential for Clean Coal Technology - Updated Estimates, Working Paper. Washington DC, October 1, 1993.

To International Energy Agency, Coal Information 1992. IEA Statistics 1992, Paris, 1993.
} 
recognized that emissions control technology such as flue gas desulfurization systems and particulate controls may be needed to prevent ecological damage. Environmental impact analyses will be conducted to determine potential environmental impacts of energy projects before implementation.

Most coal consumed in the Republic of South Africa for power production and domestic purposes is unbeneficiated. South African coal contains less than 1 percent sulfur, so sulfur dioxide emissions are currently not a problem. Ash content however is about 45 percent and electrostatic precipitators are utilized to reduce particulate emissions. Management and disposal of coal fines are a serious problem. South Africa has developed a low smoke briquetting industry designed in part, to displace the use of wood fuels. This briquetting fuel source could have positive impacts on deforestation and desertification problems in South Africa, SADC and throughout Africa. Briquetting and fines combustion technology can help eliminate disposal and other environmental problems (fires, acidification of aquifers) associated with coal fines. The U.S. has developed clean coal technologies for power generation using coal fines and briquetting that could be applied. Introduction of these technologies in South Africa could help reduce environmental and other problems associated with coal fines. South Africa's Department of Environmental Affairs has released a draft white paper on Global Climate Change. Ways of implementing economic tools to environmental protection, particularly internalizing environmental costs are being investigated. In the past power plants were built and operated to maximize output. This is about to change as environmental considerations gain greater importance and are integrated into power sector policies.

\section{TECHNOLOGY SELECTION}

Clean coal technologies are selected on the basis of the needs of the buyer. Cost, reliability and environmental performance are the main factors in selecting technologies for power generation from coal. These factors, in turn, are influenced by the properties of the available coals. The priorities for a project in a developing country differ somewhat from in a developed country. In a developing country environmental performance may have low priority unless the financing agency specifies emission controls. First costs are particularly important because it is so difficult to raise large amounts of capital. In addition, reliability and simplicity of operation is important because of the relative lack of experience of many power generators in developing countries. Proven technologies are more likely to be chosen. Other factors may also be considered depending on local social, political and economic conditions. These factors are discussed in detail in a companion report to Congress. ${ }^{\text {n }}$

Pulverized Coal With Particulate, Sulfur Dioxide and Nitrogen Oxides Controls. Most large new coal units installed worldwide over the next several years will be conventional pulverized coal units, with which there is more experience than more advanced technologies such as integrated gasification combined cycle or pressurized fluidized bed combustion. These are also less complex than most new technologies.

\footnotetext{
${ }^{71}$ U.S. Department of Energy, Foreign Markets for U.S. Clean Coal Technologies, Report to Congress (in progress).
} 
Almost all new pulverized coal units will be equipped with appropriate emissions controls and the type of controls will depend on the allowable emissions levels.

Particulate emissions will be controlled with either baghouses or electrostatic precipitators, depending on coal properties and control needs. Flue gas desulfurization may be used to control sulfur dioxide emissions. High-efficiency flue gas desulfurization methods such as wet limestone forced oxidation will most likely be used for coals containing greater than 1.5 percent sulfur. Low capital cost technologies such as lime spray drying or sorbent injection might be used for lower-sulfur coals. Nitrogen oxides emissions will probably be controlled primarily by combustion modifications, although units with severe control needs may use selective catalytic reduction.

Retrofit Particulate, Sulfur Dioxide and Nitrogen Oxides Controls. Many existing coal-fired units in developing and transitional (and some developing) countries have few emissions controls and are located in areas with severely polluted air. Retrofit emissions controls for these units may be encouraged as requirements for financing new power projects. The retrofit controls will be installed as quickly as is practical in terms of financing and construction.

The considerations in choosing the particular methods of emissions controls are similar to those for new units but must reflect the space problems in retrofitting controls on existing units. Retrofit controls will be highly site-specific and are expected to vary markedly from unit to unit. In general, retrofit controls will be chosen that are less expensive and that provide relatively less stringent control. For example, lime spray drying or duct sorbent injection with as little as $\mathbf{5 0}$ percent sulfur dioxide control may be applied. Alternatively, coal beneficiation may be used to lower the sulfur content in the coal. Retrofit particulate control will usually be accomplished by electrostatic precipitators, but baghouses may be used for low-conducting ash.

Retrofit controls are especially needed in eastern Europe and in the former Soviet Union. As stated earlier, China also has considerable retrofit needs. It is believed that most retrofit emissions control projects will be associated with national air quality plans, including emissions transport modelling and prioritization of controls.

Fluidized bed combustion (FBC) is usually selected to achieve low emissions and to better utilize low-quality fuels such as low rank coals and high-ash coals. Low sulfur dioxide emissions are achieved with limestone addition to the fluidized bed. Low nitrogen oxide emissions are achieved due to the moderate combustion temperature and even lower levels can be achieved with the addition of low cost selective non-catalytic reduction. In addition, fuel flexibility is available in fluidized bed combustion units at moderate cost. FBC is ideally suited to the low-quality coals found in Asia and Central Europe.

A number of countries in Asia and Central Europe, including China, Pakistan, Thailand, Indonesia, Poland and the Czech Republic, have many potential FBC applications. China, especially, has numerous 
small FBC units operating without limestone addition and sees large-scale FBC for power generation as attractive.

Two types of fluidized bed combustion systems are in use: atmospheric fluidized bed combustion and pressurized fluidized bed combustion. Atmospheric FBC is already in widespread commercial use. Ovar 400 atmospheric FBC units up to $200 \mathrm{MW}$ in scale are in operation and project financing can be obtained for projects up to this size. Pressurized FBC is under development to improve the efficiency of FBC. Four demonstration projects using pressurized FBC are in operation or under construction in the U.S., Spain, Sweden and Japan.

Pressured FBC is under development to improve efficiency. Four demonstration projects using pressurized fluidized bed combustion are in operation in the U.S., Sweden, Spain and Japan (in construction). This technology is more efficient than atmospheric fluidized bed combustion.

Intearated gasification combined cycle (IGCC) is usually selected to maximize generation efficiency and produce low emissions including that of carbon dioxide. An IGCC unit does not need to use limestone and produces little solid waste. An IGCC unit can be projected to have acceptable cost and superior environmental performance throughout its lifetime when compared with pulverized coal boilers with environmental controls. Other benefits include the possibility of phased construction or co-production of synthesis gas chemicals including methanol transportation fuel. IGCC can operate using any carbon-containing feedstock, providing great fuel flexibility that will be needed in many developing and transitional countries.

China is the largest potential market for IGCC. It has been active in installing coal gasification for ammonia production from coal and is now planning to install IGCC power generation units. It plans such a large increase in coal-fired power generation capacity that, in fact, it has potential applications for most clean coal technologies. China is planning to advance its technical expertise by building and operating IGCC power plants. 


\section{Chapter 3}

\section{FINANCING MECHANISMS FOR CLEAN COAL TECHNOLOGY PROJECTS}

Two distinct types of financing are required for large international power plant projects such as would employ Clean Coal Technologies (CCTs). The first type is the financing of all the preliminary activities leading to the decision by the host country and/or project developer to proceed with the project, including those activities necessary to obtain financing for construction. The second type is financing of the construction of the project itself. These types of financing differ in terms of the amounts of money required, the uses of the funds, and the nature of the transactions involved. The financing of preliminary activities obviously takes place before the financing of construction and, if the results of these activities are positive, they lead to an adequate definition of the project for it to be financed and built.

The economies of the developing and transitional countries that are the primary international market for Clean Coal Technologies are changing rapidly and the electric power industries of these countries are changing with them. As a result, the nature of needs for power plant financing is evolving. Most notably, the burden of obtaining the financing - regardless of type - is shifting from state-owned utilities to private investors, often from developed countries such as the United States. This chapter explains how this change affects the needs of U.S. firms in the marketplace for U.S. Government financial assistance.

Financing of international CCT projects is particularly complex because these projects require very large investments; often, more than $\$ 500$ million in construction and development costs are involved. In addition, CCT projects often have long lead times, especially those requiring project finance. CCT projects generally take two to five years to be financed and then require up to four years for construction. Depending on the financial structure, the principals can be at substantial risk for ten to fifteen years after the facility comes on-line.

Countries with developing and transitional economies differ from developed countries in three basic respects that can affect the financing of CCT projects. First, political risks can be extremely high. Second, it is more difficult to assess the technical, economical and financial risks of the project. Currency exchange, for example, may be a problem and electric rates may be unrealistically low. Differing accounting standards and business practices add complexity and nuance. In addition, it is sometimes necessary to evaluate the problems inherent in the transition of the power projects from a stateowned utility to independent power. Third, potential customers may be new or reorganized and have no established track record as commercial entities. Investors need assurance that the operators and customers will be able to perform according to their obligations. 
Regardless of where a complex venture such as CCT project is developed, the allocation of risk is a key part of the development and financing process. Risks are generally shared among a number of parties to the venture, including project developers, joint-venture partners, equipment vendors and service providers, the host government, the purchaser (typically a utility) and the financial community (often including foreign export credit agencies and multilateral development banks). Each party accepts those risks that it can handle in the normal course of its business. Government financing mechanisms-co-funding of preliminary activities, political risk insurance, loans and loan guarantees-have all been used for many years by the U.S. and foreign governments within this risk-sharing context. Similarly, the financing mechanisms for CCT projects described in the next chapter are also risk-sharing concepts.

As discussed below, these considerations greatly affect the abilities of these countries to obtain financing for both the preliminary activities and construction of projects.

\section{FINANCING OF PRELIMINARY PROJECT DEVELOPMENT ACTIVITIES}

Project developers engage in a sequence of activities prior to obtaining permanent funding to construct large CCT projects. Often, these developers are responding to requests or stated requirements by the governments or utilities of potential host countries. The objective of these activities is to identify potential projects, to further identify those that have acceptable risk and return characteristics, and to adequately define the projects so that they may be financed and built. Funding for these activities can be provided by private sources, by multilateral development banks or by Federal export finance agencies. Previously, in most countries, nearly all such activities were conducted by state-owned utilities using either state funding or funding from multilateral development banks.

Project developers must finance and perform the preliminary studies in order to understand their own opportunities and risks. Although the results of these studies may be shared with the host governments and utilities and thus may also benefit them, from the developer's perspective, they are primarily performed for the developer's own benefit.

The effort, time and expense required of a project developer to bring a project to the point where it can be financed and constructed are extensive. This is true of projects in the United States and it is even more so of projects in other countries, particularly developing and transitional countries. By one estimate, the effort required to perform these preliminary activities in foreign countries is five times that required in the United States.

Developing a project in a foreign country requires a thorough understanding of that country, its electric power industry stakeholders, laws and business cultures. The necessary understanding goes well beyond the requirements for technical and economic evaluations. Generally, an ongoing long-term presence in 
the country of interest is required, requiring a substantial commitment of scarce business development dollars.

\section{Types of Prelliminary Activitie}

An ongoing series of studies is performed to bring a project to financing and construction. These studies, however, are only part of the project developer's job prior to financing. Project developers must review and evaluate numerous opportunities to select those projects that best meet their investment criteria. They must establish relationships with government agencies, utilities, lawyers, prospective business partners and suppliers in the countries in which they operate. Once they have decided to proceed, they must secure all of the permits and resources necessary to finance and construct the project. Especially in developing and transitional countries, all of this effort is to some degree at risk because the "rules of the game" are often not yet clear.

Overall, three types of activities are necessary prior to project financing and construction: prefeasibility studies, feasibility studies, and project definition activities.

Prefeasibility studie are the initial activities for some CCT projects. The general objective is to screen countries and potential projects to identify the best opportunities. They vary greatly in scope, depending both on the needs of the project and the agency performing the studies. Prefeasibility studies normally involve a review of the major country and technical risk factors. The general outlook for a project is evaluated to ensure that no major impediment is obvious.

Prefeasibility studies focus heavily on country risk factors. Generally, these can be broken down into political, financial and economic categories. Preliminary technical, financial and environmental evaluations of the project are also performed in the more comprehensive prefeasibility studies. In general, while not all questions are answered in a prefeasibility study, the major issues remaining to be studied are typically highlighted, and the scope of any subsequent feasibility study is established. Prefeasibility studies can range from a simple review of $\$ 15,000$ to a comprehensive assessment of $\$ 100,000$ or more, involving extensive contracts with the stakeholders in the country of interest. They generally take from six to nine months to complete. Studies from this stage are usually performed by the company interested in being the project manager for the power plant.

Feasibility studies evaluate virtually all of the technical, financial, economic and environmental questions associated with a specific project and present not only whether the project should be implemented, but also the proposed structure. They are undertaken when a developer has strong interest in actually developing a project. Sometimes feasibility studies follow a prefeasibility study, incorporating the prior work. Often, however, a feasibility study is the first formal analysis performed for a project. Feasibility studies are detaila. enough that final project costs can be estimated with sufficient accuracy to form the 
basis for major investment decisions. Full feasibility studies for individual projects often cost in excess of $\$ 350,000$ and can take six to twelve months to complete. More complicated studies, which link a number of projects in order to assess the host country's medium- to long-term power needs, can easily cost more than $\$ 1$ million to prepare, and are often conducted in stages. It is financially risky to perform these studies unless the funder has strong reason to believe that the firm performing the study has a high probability of obtaining the contract and, therefore, the high likelihood of an adequate return is high.

Proiect definition activities are undertaken when the feasibility of a project has been established, but the total financing package has not yet been put into place. All of the final organizational, constructionrelated and financing decisions are completed to prepare for closing on the financial package and for the start of construction. Project definition activities can allow the project to proceed, without losing momentum while waiting for the closing on the complete financial package. This additional design work can also be important for obtaining financing.

By this point in a project, the speculative risks have been reduced significantly, and the country risk issues have generally been reduced to an acceptable level. Project developers generally have a high conifort level and a high level of confidence in a project's ability to be successfully financed. During this stage, however, the required financial commitment from the project sponsor will increase dramatically, in order to bring the project to a final design, with all of the permits and agreements required to obtain financing.

The level of effort required at this stage is extensive. For example, 1,500 to 2,000 engineering drawings may be prepared, numerous permits obtained and key contracts negotiated. To support this effort, millions of dollars may be committed. Yet, the risk that the financing will not be successful is still real, potentially leaving the project sponsor with a loss of several million dollars.

\section{Private Enancing of the Preliminary Activities}

While these preliminary activities are a key part of the business of a project developer, the internal capital available for early project evaluations is often limited for both large and small U.S. firms. Even large firms may be unwilling to regularly risk the hundreds of thousands or millions of dollars that preliminary activities cost. Companies are more likely to fund the earlier feasibility assessment stages, which have a much lower cost and can be categorized as ordinary business instead of investment risk. The decision to use internally-generated funds will depend on a number of factors in addition to the cost, including the likelihood of earning a return on the investment, the budget that a manager has available for the investigation and the relative risk/reward ratios of alternative projects available to the firm.

If additional private funds are needed in the future, possible sources might be U.S. venture capitalists, or institutional investors who provide venture capital, who could conceivably take an early equity position 
in these power facilities. This would not only open up new private sources of funds for feasibility studies, but also sources of equity capital for project financing of the CCT power plants that proceed to development. For venture capitalists or institutional investors to become involved, they need to:

- Understand and feel comfortable with the industry and country risks,

- Foresee the ability to make a high rate of return on their equity capital, and

- Feel highly confident that they can achieve liquidity in their investment within a threeto five-year time period.

Institutional irivestors are only now becoming involved in such overseas development and, for the most part, it is in the later financing of the project itself.

\section{Pole of Multilateral Develonment Banks}

The major multilateral development banks provide financial resources for prefeasibility and feasibility studies. Institutions such as the World Bank have traditionally funded preliminary power plant development activities. They were considered to be the type of public infrastructure investment these institutions were organized to fund. The host country typically lacked the money and the technical ability to have the studies done properly. Today, such studies are usually necessary to interest foreign investors in projects in the lesser developed countries. The leadership of the multilateral development banks provides credibility that the studies have been correctly and objectively prepared. The multilateral development banks also fund non-project-specific programs to enhance the ability of developing countries to run an efficient, environmentally-responsible, economically-sound utility sector.

The U.S. is a major shareholder, playing a key role in the most important multilateral development banks. The shareholders of these organizations, however, include many industrial nations in addition to the United States. When funds are distributed to a project, no consideration is given to assuring a prorated distribution of contracts to firms in the contributing countries. As a result, there is a low likelihood of U.S. firms receiving contracts in proportion to U.S. funds contributed to the bank. Multilateral development bank programs in which the United States participated are summarized in Table 3-1.

\section{Need for U.S. Government Financial Assistance}

U.S. developers have project development opportunities both in the U.S. and overseas, many of them in developing and transitional economies. In order for U.S. developers to be willing to develop projects overseas, the risk and rewards of the projects must be at least comparable to those of domestic projects. Indeed, given the higher risks, the potential returns must also be higher. Without U.S. government assistance to match foreign competition and to reduce the high front-end risks, private industry can be expected to underinvest in prefeasibility and feasibility studies for foreign CCT projects. 
Active involvement at the earliest possible stage of prefeasibility or feasibility assessment is crucial for U.S. firms. This involvement greatly increases the likelihood that U.S. CCT vendors or developers will be chosen, and that U.S. firms will subsequently be strong contenders to develop the projects. Relationships established at this time may continue throughout the life of the project. Early decisions shape all subsequent ones, and early involvement provides information that is otherwise unavailable. It is particularly important at this stage to establish relationships of mutual trust with potential customers. This requires active efforts to seek out and define projects.

The risk inherent in many preliminary project development activities often makes it difficult for private U.S. firms to fund these activities. Not only are the business risks greater, but it is also less likely that the project can be financed. These expensive studies are considered to be very risky to perform, even by the larger companies, because the potential for coming up empty-handed is large. There is strong reluctance to perform a feasibility study without substantial financial aid unless a firm is certain that it, and not a competitor, will win the project.

Table 3-1

\section{PREFEASTBILITY/FEASIBILITY STUDIES AND PROJECT FINANCE: MULTILATERAL DEVELOPMENT BANKS}

\begin{tabular}{|c|c|c|c|c|c|c|c|}
\hline NETTIUTION & PROORAMB & $\begin{array}{l}\text { ANT. AVAILABLE: } \\
\text { TOTN PER } \\
1093 \text { PRONECT }\end{array}$ & $\begin{array}{l}\text { PERCENT } \\
\text { PAIDEY } \\
\text { IMSTITUTION }\end{array}$ & QUALIFICATIONS & $\begin{array}{c}\text { OTHER } \\
\text { PRONISIONS }\end{array}$ & $\begin{array}{l}\text { PARTY } \\
\text { REQUESTINO } \\
\text { FINANCINO }\end{array}$ & $\begin{array}{l}\text { TEPAYNENT } \\
\text { UPON } \\
\text { SUCCESB? }\end{array}$ \\
\hline $\begin{array}{l}\text { licit: } \\
\text { Crowp }\end{array}$ & 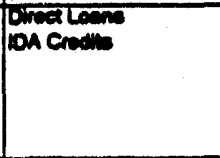 & $7+25=\mathrm{NW}$ & 40565 & 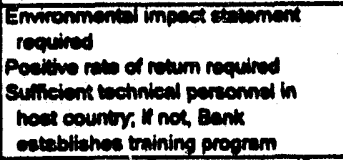 & 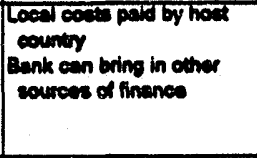 & How cound & \\
\hline 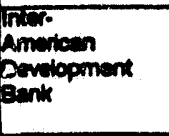 & 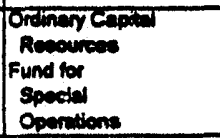 & 868 & $50-80 \%$ & 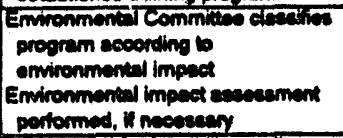 & $\begin{array}{l}\text { Bank colinances } \\
\text { programs with other } \\
\text { organtadions }\end{array}$ & Post counting & \\
\hline 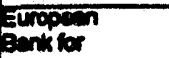 & $\begin{array}{l}\text { Tormied dooperion } \\
\text { Funding }\end{array}$ & STOOT NA & TNA & 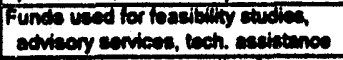 & $\begin{array}{l}\text { Emiconmentaly } \\
\text { cound project }\end{array}$ & Hod country & N \\
\hline $\begin{array}{l}\text { Reconemuction } \\
\text { and } \\
\text { Dewigoment }\end{array}$ & 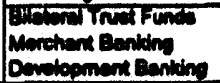 & 5K: & 365 & 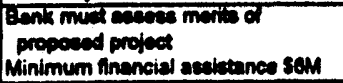 & $\begin{array}{l}\text { Eonk propeles in } \\
\text { cohunding with } \\
\text { World Bank }\end{array}$ & How country & \\
\hline ก.T & 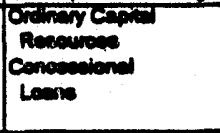 & ABE" & aloin & 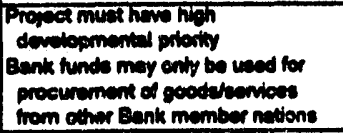 & 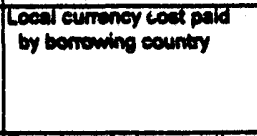 & Hod county & \\
\hline & 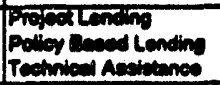 & $\begin{array}{l}\text { T2E } \\
510 \mathrm{M}\end{array}$ & $35 \%$ & 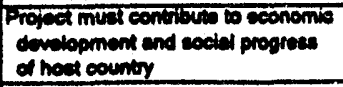 & 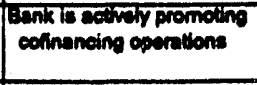 & freatcounty & \\
\hline & & & & & & hourcowny & Y.N \\
\hline
\end{tabular}

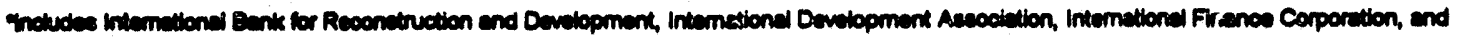

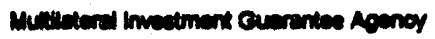


Some of the primary deterrents to private funding of feasibility studies in foreign markets are listed below:

- Preliminary activities take longer and cost more in developing and transitional countries. More work may be needed to define the project and establish the legal and regulatory basis to build and operate it. Moreover, conducting operations in foreign countries requires a substantial overhead commitment to those countries beyond a company's domestic operations.

- For projects in developing and transitional countries, the initial analysis by the government or state-run utility is often incomplete and there is no reliable commitment that a plant will be built. In contrast, for an independent power project in the U.S. or most developed countries, the utility determines needs for new power plants through detailed capacity expansion plans, and thus can make a firm commitment to a new utility-owned or independent power capacity.

- Foreign projects are more difficult to evaluate, and thus their studies are more expensive to perform, because of the foreign risk analysis component. Even for experienced multinational corporations, country risks are difficult to analyze and mitigate. An incorrect analysis can result in an abrupt cancellation of a project, a loss of credibility in the international marketplace for the project developer, as well as a large financial loss.

- Studies funded by foreign governments on behalf of their companies may offset the U.S. technical edge on CCTs. These studies are either subsidized directly by a government entity or by co-funded multilateral development bank grants. Once the foreign companies are awarded the feasibility study, they will work to position their technologies as the best solution for the project.

- These studies are too speculative for commercial or investment banks to fund. Those lending institutions do not provide initial, speculative capital especially for these high-risk transactions.

\section{U.S. Government Financial Assistance Programs}

As part of the Administration's National Export Strategy, the Trade and Development Agency (TDA) is to be given sole responsibility for financing prefeasibility and feasibility studies. These studies are funded by loans to U.S. firms, which are usually expected to be at least partially repaid if the U.S. firm is awarded the project. In other instances, the funds are considered outright grants to the host country as a form of economic aid. Funding for prefeasibility and feasibility studies was previously available from the TDA, Agency for International Development (A.I.D.), the Export-Import Bank (Eximbank), the Overseas Private Investment Corporation and DOE. This transfer of responsibility is currently in process. Funds that were available for coal projects through DOE's Federal International Trade and Development Program (FIETOP) will continue to be available through TDA. TDA also has market 
study programs involving definitional missions, technical symposia and orientation visits that meet some of the goals of some prefeasibility and feasibility studies.

Most of the available funding is for preliminary activities in prefeasibility or feasibility studies. Relatively little multilateral or bilateral funding is available for the later and more expensive project definition activities that are crucial to obtaining construction financing.

Government support of the preliminary activities provides several crucial underpinnings to U.S. industry. Such support allows U.S. firms to compete on a more level playing field with foreign competitors provided similar assistance by their countries. It provides leverage to pursue more opportunities and reduces risks. For advanced technologies, this support adds credibility to the project in the eyes of host company investors. In addition, since utilities in many countries are government-owned, government-togovernment relations are often the key to opening doors.

\section{FINANCING OF PROJECT CONSTRUCTION}

Traditionally, conventional full-recourse borrowing by utilities and governments has been used to finance power projects. Today, with the availability of such funds highly limited, non-recourse and limitedrecourse financing of independent power projects are increasingly being used. Depending on the country consideration, both techniques may be used in the future.

\section{Cenventional Utility and Government Finance}

Once the decision has been made to build a power plant, it is necessary to determine the type of financing mechanism that will be used. A major source of hard currency credit for power projects in developing countries (and now in transitional countries) has been loans from the multilateral banks and loans, loan guarantees, and grants from the governments oi individual developed countries. This credit is generally referred to and reported as official credit. It is likely to remain a major hard currency credit source for future developing and transitional country power projects. Official credit is preferred by developing countries because: (1) the effective interest rates and payment terms are usually more attractive than those for the two other forms of hard currency credit; and, (2) this type of credit frequently is required before other lenders will become significantly involved in power projects. Currently, official credit levels for lending to qualifying countries for power projects is approximately $\$ 6$ billion per year.

In addition to official credits, two basic options are available to obtain funds from the private sector: general credit and project finance. The first alternative, general credit (full recourse) financing is generally preferred by the utility because it is both a less expensive and a generally more expeditious method of financing. It is available to international borrowers with excellent credit histories, good 
economic prospects, and in cases where the country has adequate currency reserves. In the international CCT industry, general credit is most often used by a strong entity that will build, own and operate the power plant. The entity is usually a state-owned utility, building a power plant for itself or retrofitting an existing plant with pollution control technology. In these cases, no discrete revenue source can be applied to the repayment of the financing for the project. Thus, in general credit finance-

- The funds supplied by the commercial and investment banks are a general obligation of the borrower.

- The financing entity must look solely to the overall operating revenues and assets of the borrower, which may be the utility and/or the government, for repayment.

- In some circumstances, the banks might also be granted liens on specific major pieces of equipment or other assets of the utility, which they may attach if payments are not made. This is not always a practical solution for the bank, because seizing assets could jeopardize all future payments.

General credit finance usually requires an equity component on the part of the utility. For strong borrowers, the debt/equity ratio primarily depends upon the cost of capital to the utility for the various sources of funds. For less credit-worthy borrowers, the provider of the debt will require the equity portion to be a certain percentage (ranging from 20 to 30 percent) of the total cost to provide a safety margin for the debt.

Potential lenders look at the overall operating and financial history of the utility to see whether it can afford to service the debt on the new facility. If the utility is not expected to have a sufficient cash flow to safely service the debt incurred to retrofit an existing plant or build a new power plant, then the first place the lender looks for additional financial assurances is the government of the host country. In the absence of adequate cash flow from the utility, the host government must be willing to provide the necessary guarantees of additional payments to allow for financing of the transaction to occur.

If the country is weak financially, or lacks currency reserves, then the risk is higher, since specific revenues are not attachable to secure the payment of the debt, and funds may not be available for the payments. In fact, at that point the only security is the good faith and credit of the host utility or government, perhaps supplemented by the ability to repossess some of the assets. In current economic times, for developing and transitional economies, this is usually insufficient to obtain financing, especially where seizure of assets is not a realistic alternative. 


\section{Difnculties in Financing Using Conventional Techniques}

Starting in 1982, an escalating international debt crisis caused substantial reductions in sovereign lending from private sources - such as international bankers - to developing countries. Voluntary medium- and long-term general purpose financing from commercial banks to highly indebted countries all but ended. Thus, many developing countries and countries with transitional market economies currently have significant problems financing new or upgraded power plants through conventional borrowing. There are several reasons:

- Sufficient capital from within the developing countries is unavailable. These countries usually do not generate sufficient internal capital to support all of their infrastructure needs, and they lack viable capital markets in which adequate additional funds can be raised. A recent World Bank stuoiy found that although in some developing countries one-quarter to one-third of the public resources available for investment are being devoted to electric power projects, these investments are still inadequate. While some of the stronger developing countries can partially finance power projects with bonds, in other countries no formal capital markets exist to provide funds. In some of these countries, private industry and/or private capital does not legally exist; in many transitional countries, risk-taking is still too new a concept for easy implementation of viable capital markets. The development of these markets, while important to the growth of their economies, will not be a quick or simple task. Not only must the market be created, but the buyers of the securities must understand and gain confidence in both the stock and bond markets, as well as in the companies in which they would be allowed to invest.

The countries lack adequate sovereign credit to finance utility-owned power projects. This is a result of the repudiation of loans by a large number of the developing countries during the early 1980s. Commercial and investment banks and their regulators throughout the world are wary of loans made to these countries. In addition, risk levels increase proportionately with the amount of time the risk is outstanding; developing and transitional countries have very uncertain medium- to long-term risk profiles. Thus, what little sovereign credit they do have tends to be short-term, while the debt repayment requirements for CCT projects almost always exceed 15 years.

- Many utilities owned and operated by government agencies do not have adequate credit ratings and are burdened with poor financial and operational track records. Thus, they can not be financed in the same way that a utility in the U.S., or other developed countries, is financed. They cannot go to international credit markets because they do not have internally generated funds for repayment.

- Due to losses suffered in this sector, multilateral development banks (which are faced with growing requirements for financial assistance) are re-evaluating the amount of funds they are willing to put directly into individual power projests without participation from private investors. They realize that the sector's needs are far greater than their own resources. In addition, as the energy sector in many countries continues to privatize, entities such as the World Bank Group may need to cut back on energy 
lending because the World Bank's charter does not allow it to lend money to private entities without a host government guarantee.

\section{Inancing Clean Coal Technologies}

CCT projects are typically larger, take more time to build and are more capital intensive than power projects fueled by oil- and gas-fired plants. More is thus at risk. In addition, the sheer size of these projects (often over $\$ 500$ million) means that the funds have to come from multiple sources, complicating both the financing process and the financial structure. Thus, financing has become an especially important determinant in the selection of a project manager for CCT projects.

Technological risk is also considered by both customers and the financial community. To hold that risk to an acceptable level, developing and transitional countries would typically choose only commercially-proven technologies. The newer, more advanced technologies lack the track record with which customers and the financial sector must be comfortable. This concern is intensified when developing and transitional countries consider operating the facilities themselves.

\section{International Independent Power Project Development}

The development of independent power projects provides the only viable alternative for many countries to bring on line new generation capacity. This concept was originally proven in the United States, and U.S. practices provide a proven, working model for projects in many countries. Moreover, multilateral development banks, such as the World Bank, see independent power as a way to leverage their investments. As a result they are taking steps to encourage project-finance-based independent power development as a way to meet the growing energy needs in developing countries.

Experienced entrepreneurial project development and operating companies have evolved in the U.S. over the past fifteen years. They have substantial experience financing, building and operating environmentally sound power plants including those using CCT. Many of them are active in overseas markets and are thus uniquely qualified to act as project managers in developing and transitional countries.

U.S. firms, however, are not alone in the international private power market. Foreign developers have also emerged to compete with U.S. companies. In many cases they have benefitted from substantial aid from their governments. This includes government-to-government assistance on project feasibility and tied-aid or other methods to provide low-cost funds for their companies. Several governments have then extended low-cost financial aid to their companies either directly, through quasi-governmental agencies, or by persuading their banks to lend at below-market interest rates. 
The independent power alternative has already changed the international market for power plant equipment. The independent power sector is emerging worldwide and will probably be the fastestgrowing market segment in the world's power supply sector over the next five to ten years.

U.S. firms have an advantage in the independent power arena. The Public Utility Regulatory Policies Act of 1978 (Public Law No. 95-617, 16 U.S.C. 2601) and the evolution of the independent power project concept in the U.S. created an entrepreneurial industry to build and own independent power projects ahead of most international competitors. Independents are either already involved overseas or are capable of making the transition, since their experience levels are second to none. Financing mechanisms for independent power projects also evolved in the U.S., putting U.S. financial firms on the forefront of understanding and defining the operational requirements of this specialty financing. These early advantages will not, however, be enough to compete successfully in the rapidly-growing international marketplace. Foreign companies have learned quickly and are able to compete very effectively.

\section{International Project Finance}

Project finance has been a viable financing mechanism for a number of years. It is now being used to allow power plants to be built by developing and transitional countries in the absence of adequate longterm sovereign general credit. In a "pure" project finance transaction, the host country would not bear any of the risks of the power project. Rather, the lenders would look solely at the assets and earnings of the borrowing entity for repayment of the loans. Most of these CCT power plant transactions in developing and transitional countries are actually considered to be "quasi" project finance transactions, because the host country is still required by the lenders to assume a limited portion of the risk through various undertakings.

Project finance has been demonstrated as a viable form of financing CCT power projects. More than $\$ 30$ billion worth of independent project financing has been completed through 1990, and annual growth has averaged 20 to 30 percent. These power projects are large enough in scale to be attractive to major project developers and investment bankers.

Developing the structure and gaining agreement on all of the requirements of each specific project is usually the job of the investment banker, who is hired as an advisor by the project manager. The investment banker's goal is to cover all of the financing requirements while managing the outstanding risks and minimizing the need for equity (versus debt) in the project. They perform the "due diligence" on the transaction to make sure that the interests of the investor are protected. They are also instrumental in raising the funds from investors. 
Project finance methods are the preferred method for independent power development. By spreading risks to those parties willing and able to assume them, and requiring a thorough job of setting up and documenting the transaction, project finance can actually be less risky to both the financial institutions (public and private) and the host government than is sovereign financing, where the entire risk is assumed by the host country. This is especially true when project finance results in bringing outside, highlyqualified operators into these countries to run the new and, perhaps, existing power plants. Where this happens, the power plants generally operate more efficiently and economically, further lessening the risk. In many countries, strenuous objections may be made to the hiring of outside operators, but this will often be necessary in order to finance the project.

Participants in Project Finance Transactions. Project finance involves setting up an independent company to replace the host country as the builder, owner and/or operator of the power facility. It may be part of a "privatization" of the utility industry in a given country, which would allow this financing format to be used for new or repowered facilities. The intent is to create a project entity that is able to operate profitably under market economy conditions, without interference by the host country.

Project finance uses the same principal players and many of the same contractual elements as a general credit-financed project, but it must accomplish a more thorough job of allocating risks because none of the involved parties has the "deep pockets" to backstop the transaction. Project finance is predicated upon contractually delegating portions of the risk to the appropriate parties, making sure that all of the risk is covered, so that the transaction as a whole has a reasonable set of overall risk/reward characteristics and a manageable dollar amount of exposure for each of the specific participants. No risk can be left uncovered because, unlike a general credit transaction, the lenders cannot look to any other revenues or assets as a source of repayment. In a typical project finance transaction, the following participants can be required by the project developer or the lender to cover their allocated risk:

- Architecture and engineering firms assume the risk of proper design of the facility.

- The constructor assumes the completion risk, to include the actual completion of the plant, as well as meeting the construction schedule and delivering the project at the contracted cost of construction.

- Various equipment vendors take on the risks associated with delivering components to the project.

- The project manager assumes the risk for operating the plant to agreed-upon efficiency and economic parameters.

- Various financial entities, including the host country, multilateral development banks, bilateral development agencies and private capital, take on a specified portion of the financial risk so that the revenues from all sources will cover both operating costs and 
debt service. This may be provided in the form of direct investment, guarantees or political risk insurance.

- Fuel suppliers and transportation companies agree to supply fuel to the plant under specified parameters.

- The utility customers (off-takers) accept the risk that they will be able to pay for the power that is provided.

This approach means that no one party must assume risks that they have not been compensated for, and it allows the project manager to finance the project on a limited-recourse basis once the project is on-line and meeting specified operating criteria.

Dinancial and Operatine Structures. Three basic types of financial and operating structures have been developed for use in project finance transactions. In every case, they involve initial ownership of the project by a private entity, normally the project developer(s). The actual ownership structure is usually very complicated, as the owners try to take advantage of the optimal tax and financial structure.

Operating structure alternatives differ primarily in the amount of time that the project is owned and/or operated by the project manager prior to the potential transfer of the facility back to the host government or utility, or other entity. In general, the investors want the ownership to remain with the qualified private operator for as long as possible in order to maximize their potential return. The host country, as discussed previously, wants to regain ownership as soon as possible for political reasons. The deciding factor is normally the time at which the host country will have the ability to take financial responsibility for the project. The following three structures are most commonly utilized:

The Build, Own, Operate (BOO) scenario is utilized when the investor maintains longterm ownership and operational control of the project. This structure provides the investor with the greatest control, the longest time to achieve a return on investment and, therefore, potentially the lowest risk.

- The Build, Operate, Transfer (BOT) method is, in effect, an installment sale to the host government or its utility. It allows a ccuntry to gain ownership of the project once the debt and equity is repaid. For any remaining financing to stay in place upon the transfer, the financial parties must have a strong comfoit level with the ability of the host country or its utility to efficiently and profitably operate the facility. In most cases, this will be a very difficult case to make because the utility will have either an unsatisfactory or an insufficient operating history. Rehabilitate, Operate, Transfer (ROT) is a variation of the BOT used for rehabilitation of existing generation plants. A ROT is similar to a BOT except that it adds a preliminary operating stage to allow the operator to become familiar with the facility in order to best identify potential improvements. 
- Build, Transfer, Operate (BTO) is essentially a "turn-key" construction contract. The project developer assumes the construction risk and then transfers the project to the host country or its utility as soon as the power plant is placed into service. Often the original project developer will continue to operate the plant on a contractual basis. It is unlikely that developing or transitional countries, lacking both short-term currency availability and long-term sovereign credit large enough to cover these massive projects, will be able to utilize this structure under current credit conditions.

\section{Inrolvement of Multilateral Finance Organizations}

Multilateral development banks are heavily involved in providing loans and guarantees for project finance transactions in the energy sector. In many cases, the programs are the same as the ones used to fund prefeasibility and feasibility studies. These institutions specifically target both developing and transitional countries with this aid, but do not care which country the project management firm comes from. The multilateral development banks, through competitive bidding, attempt to obtain the best product at the best price. Since U.S. CCTs and project developers are among the best, this can be an advantage for U.S. firms if the playing field for costs is level. Of the multilateral development banks, five are most relevant to CCT projects due to available financial resources, geographic mandate, or both: the World Bank Group, the European Bank for Reconstruction and Development, the Asian Development Bank, the Inter-American Development Bank and the African Development Bank.

Greater coordination between U.S. agencies and the multilateral development banks will lead to more effective overall assistance. Coordination would eliminate some duplication of efforts and increase the flow of information to U.S. firms, hopefully resulting in more U.S. firms bidding on multilateral development bank projects. The coordination would thus result in an increase in the total assistance available to U.S. firms. The office of the U.S. Executive Director, staffed with employees of the Department of Commerce, and the Office of Multilateral Development Banks at the Department of the Treasury are available to provide assistance to U.S. firms attempting to obtain contracts from the World Bank.

\section{Needs for U.S. Government Financial Assistance}

The needs for financial assistance for project development differ from the preliminary financing needs outlined earlier. Here the key risks are long-term structural investment risks, which are an outgrowth of economic and political uncertainty. Risks derive from the large size of these projects, the inability of the host country or utility to obtain financing based on sovereign credit, and the general difficulty that investment bankers say they are having in obtaining both debt and equity funds from the private marketplace. These CCT power projects need the discipline brought on by the presence of qualified operators as well as the multilateral development banks, bilateral financing agencies and private investors. 
Often, the presence of U.S. government and/or multilateral development bank financial assistance lends credence to the necessary assumption that the host country will not purposefully take action to cause the project to go into default, because that would be causing negative consequences not just to a private entity, but also to a governmental one. A country may not need future help from the private entity, but it probably will need assistance from the multilateral development banks and/or government entities.

U.S. government assistance makes the projects more financeable and levels the playing field for U.S. developers both to be hired as the project developer and as the long-term operator. Financial assistance also enables the financing to close by helping alleviate and allocate the investment, and therefore the risks.

Three basic types of U.S. government aid are needed:

- Direct U.S. government fnancial assistance starts with agencies committing to fund a share of the total loan requirements. These loans are expected to be repaid and also function as a catalyst to get private funds involved.

- Guarantees and insurance programs are the second level of involvement, which additionally leverages the total cash available by backstopping the private sector financing institutions. Bank loans backstopped by U.S. agencies receive favorable treatment from bank regulators.

- U.S. agency involvement also helps provide better coordination, with the multilateral development banks, in the quest for additional financial assistance from them.

\section{U.S. Government Assistance Programs}

Four U.S. agencies have been actively involved in providing financial assistance to project developers for international project finance CCT transactions. The Overseas Private Investment Corporation (OPIC) and the Export-Import Bank of the United States (Eximbank) provide a variety of services, including direct loans, loan guarantees and various types of insurance. The Agency for International Development has not been active in financing transactions for energy projects for a number of years, but does support infrastructure development. The Small Business Administration (SBA) has programs that help small business exporters of goods and services to these projects but, for the most part, these companies are suppliers to primary contractors. SBA has no direct role in project financing, thus it is not a major resource contributor. The programs of all four agencies are summarized in Table 3-2. U.S. export finance agencies are only now organizing themselves to deal effectively with large international power project finance transactions because of their limited experience with them. These projects are larger, more complex and different than the typical exporting program that might just require the use of U.S. agency guarantees. The role of the agency is thus as an involved party to the transaction, not just a guarantor. In addition, U.S. agencies are often more conservative than financiers of domestic 
independent power projects. They are used to relying on host country guarantees as the ultimate repayment source for a transaction, but now they must spend considerably more time and effort evaluating all of the parties and the agreements between them in these limited-recourse transactions. And, they must become experienced with the different structures for risk reduction, since they are not primarily relying on the sovereign guarantess. U.S. export credit agencies adhere to the Organization for Economic Cooperation and Development Arrangements on Guidelines for Officially Supported Export Credits (OECD Arrangements on Export Credits), which puts limits on the form and term of the assistance they can provide. Eximbank and other export credit agencies, for example, must adhere to the 10-year term limit (12-year limits can be considered if the offering country complies with a notification process) except in the case of tied-aid offers. Eximbank has limited "war chest" funds available for matching foreign concessionary financing. The OECD Arrangements on Export Credits permit tied-aid for projects that are not commercially viable. The determination of commercial viability is done on a case-by-case basis, and CCT sales may be viable or non-viable.

Table 3-2

IINANCIAL ASGISTANCE OFTERED BY FDDERAL AGENCIES

\begin{tabular}{|c|c|c|c|c|c|}
\hline $\begin{array}{l}\text { DEPTJ } \\
\text { AQENCY }\end{array}$ & PROGRAMS & ASSISTANCE & QUALIFICATIONS & DETAILS & $\begin{array}{l}\text { PERCENT } \\
\text { FINANCED BY } \\
\text { INSTITUTION }\end{array}$ \\
\hline oile & $\begin{array}{l}\text { Progen } \\
\text { Imveriment insurences } \\
\text { Progen }\end{array}$ & 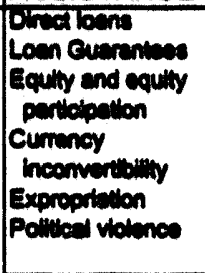 & 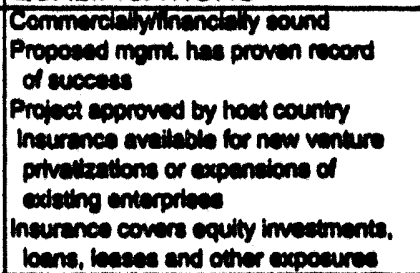 & 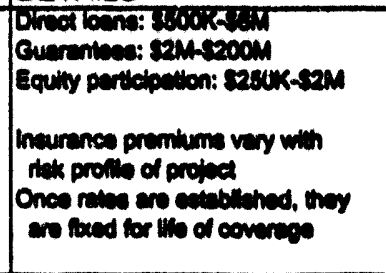 & 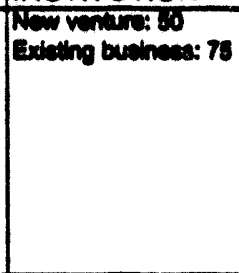 \\
\hline DUITANRK & 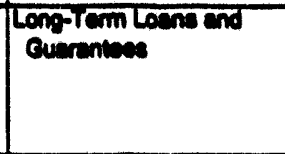 & 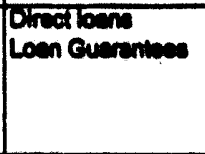 & 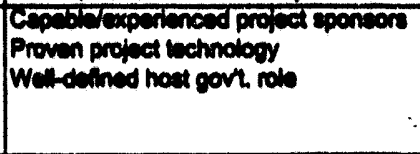 & 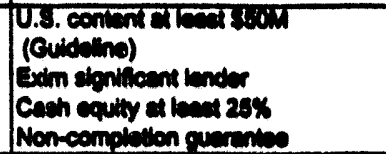 & 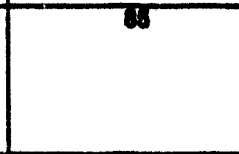 \\
\hline Mr.o. & $\begin{array}{l}\text { Whay proper } \\
\text { Development fund } \\
\text { (Epof) }\end{array}$ & 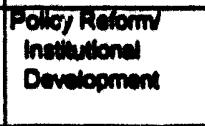 & 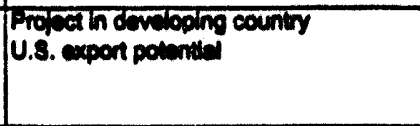 & 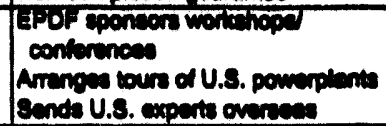 & Wh \\
\hline
\end{tabular}

U.S. government assistance is not additive. That is, individual programs may be used under conditions which would preclude other programs from being available. The process of weaving government and multilateral development bank support with private sources of capital is not an easy process because some agencies and/or multilateral development bank programs are meant to benefit sovereign nations, and some 
are to be used in the private sector. In addition, qualification criteria vary, and some are mutually exclusive.

\section{LEVELS OF SUPPORT POTENTIALLY NECESSARY}

U.S. Government financial assistance will be needed for both preliminary activities and the financing of power plant projects. A recent study commissioned by the U.S. Department of Energy found that the international market for CCTs was quite large, with an expected value on the order of $\$ 714$ billion between 1993 and 2010, an average of $\$ 42$ billion per year, of which $\$ 36$ billion is for the initial investments. ${ }^{2}$ The overall market size ranges between $\$ \$ 71$ and $\$ 870$ billion. The future U.S. market share cannot be known, but, given the strong position of the U.S. international project development industry and the U.S. technical lead in Clean Coal Technologies, a significant market share could be achieved.

Table 3-3 presents estimates of the annual average levels of Federal financing support potentially required between 1994 and 2010 by U.S.-developed CCTs for both new projects and projects where a CCT is retrofit to an existing power plant. These estimates are derived from the CCT market size estimates described above. ${ }^{2}$

Assuming that all U.S. projects would request financial support of some type from the U.S. Government, total Federal support is estimated at between $\$ 1.1$ and $\$ 2.9$ billion per year. Of this, only roughly eight percent is devoted to the preliminary activities. The great bulk of the financial support is devoted to the financing of the projects themselves. Such financing can take the form of loans and loan guarantees by EximBank and OPIC. OPIC is also authorized to be an equity participant in some projects.

\footnotetext{
'Resource Dynamics Corporation, Market Potential for Clean Coal Technologies: Updated Estimates, Report to U.S. Department of Energy, October 1, 1993.
}

The methodology used to develop these estimates assumes that: 1) the market potentials estimated in the study cited in the previous footnote are achieved, 2) U.S. firms realize a market share between 20 and 33.3 percent of the market, and 3) all U.S. firms use U.S. government assistance. Needs for U.S. government assistance for project construction are calculated for the U.S. share of international projects by estimating that the Government finances, on average, 70 percent of the typical U.S. content of such projects. U.S. Government financing of the preliminary activities is calculated by multiplying: 1) the number of such activities likely to be carried out to produce the number of successful projects built by 2) the typical U.S. Government share of the costs of such activities. Calculations and assumptions were circulated to the EximBank, OPIC and TDA for comments and were refined based on these comments. 
The average amount of U.S. Government financial support for a project is estimated at about $\$ 150$ million for a new facility and $\$ 30$ million for a retrofit project. It is anticipated that 5 to 15 new facility and 9 to 15 retrofit projects per year would be developed by U.S. firms.

Loans and Loan guarantees of between \$1.1 and \$2.9 billion per year on average between 1994 and 2010 would represent a considerable share of the financings of U.S. export credit agencies. In 1993, the Eximbank made $\$ 10.8$ billion of financing commitments, of which $\$ 1.7$ billion were loans and grants and $\$ 9.1$ billion were loan guarantees. Of the $\$ 10.8$ million, $\$ 3.1$ billion was to the energy sector. ${ }^{3}$ Also in 1993, OPIC made $\$ 415$ million of loans and loan guarantees, of which 42 percent was for projects in the energy and environmental sectors. "The same year, TDA incurred obligations of $\$ 42.5$ million, of which $\$ 13.8$ million (32.5 percent) was for projects in the energy and natural resources area. 3

These figures somewhat understate the impact of these additional requirements on U.S. export credit agencies. CCT projects represent only a part of the related power sector and energy production investments required worldwide over the next twenty years. Investments and preliminary studies will also be required for other types of power plants, for related electric power systems (e.g., for electric transmission) and for fuel production and transportation facilities. In addition, much of the financing requirement will be for longer-term financings than is typical of U.S. export credit agencies.

As discussed earlier, most of the projects can be expected to be financed using project finance methods. Project finance transactions are highly complex and require extensive review on the part of export credit agencies beyond that normally given to corporate or sovereign finance transactions. Project finance of international power projects is relatively new. The U.S. Federal export credit agencies will need to develop considerable new capability and expertise in order to process this number of project finance transactions in a year. Further, the numbers of projects listed above refer only to potential CCT projects. They do not include the many natural gas (and other) fueled projects also to be project financed. This issue was discussed extensively in a previous DOE report to Congress. ${ }^{6}$

${ }^{3}$ Export Import Bank of the United States, 1993 Annual Report, pp. 18-29

‘Overseas Private Investment Corporation, 1993 Annual Report, pp.20-22

${ }^{3} U$.S. Trade and Development Agency, 1993 Annual Report, Figures 1 and 12

- U.S. Department of Energy, Clean Coal Technology Export Finance Programs, Report to the United States Congress, September 30, 1993. 
Table 3-3

\section{POTENTIAL ANNUAL U.S. GOVERNMENT FINANCING OF INTERNATIONAL CCT PROJECTS (Million Dollars per Year)}

\begin{tabular}{|l|r|r|r|}
\hline & \multicolumn{3}{|c|}{ Case } \\
\hline & Low & Base & High \\
Total Miarket Size & 29,000 & 36,200 & 44,100 \\
(Initial Investments) & & 25 & 33 \\
U.S. Share (Percent) & 20 & 1,618 & 2,641 \\
\hline Project Construction & 1,027 & 148 & 287 \\
\hline Project Definition & 96 & 17 & 8 \\
\hline Feasibility Studies & 4 & 5 & 2,915 \\
\hline Prefeasibility Studies & 3 & 1,788 & 28 \\
\hline Total & 1,137 & & \\
\hline
\end{tabular}

Source: $0 . S$. Department of Energy estimates.

From a public policy perspective, the benefits of providing financial assistance need to be greater than the cost. By helping increase the export of CCTs and providing U.S. project developers with more opportunities, funds devoted to preliminary activities are extremely cost-effective:

- An outlay ranging from $\$ \mathbf{\$ , 0 0 0}$ to $\$ 5$ million can result in contracts to U.S. firms in excess of $\$ 100$ million. Due to the large total size of these CCT projects, often worth in excess of $\$ 500$ million, a U.S. firm can get substantial benefits from becoming the project developer. A tremendous multiplier effect occurs from these early investments. Helping U.S. firms win these contracts will result in jobs, exports and a subsequent improvement in the U.S. trade balance.

- The cost of the studies is repaid once the U.S. firm has been awarded the project and the financing is completed. Initial studies are low in cost. The only time that incremental sums continue to be spent by the U.S. government on the various levels of feasibility studies is when the project feasibility continues to hold up. Only the funds spent for studies which do not result in a project become a true cost to the U.S. government. 
- The public benerits can extend to far more than CCT projects. Since power projects are the first infrastructure project to be developed by many of these countries, successful participation by U.S. firms can position other U.S. firms to capitalize on export opportunities in all sectors of a country's infrastructure. This would include other types of power projects, infrastructure projects and manufacturing facilities.

\section{IMPLICATIONS}

International CCT projects require large investments that may be difficult for developing and transitional countries to finance. In most cases, project finance methods will be used. The development of these projects requires support from export credit agencies or multilateral development banks. Financing programs from these organizations address the more usual forms of commercial and political risks. The number of such transactions is expected to increase rapidly over the next 20 years and countries desiring to build power projects will have to seek large amounts of private capital because their requirements exceed the capital available from export credit agencies and multilateral banks.

Advanced CCT projects may add the additional dimension of technology risk. CCTs that are not yet proven are beyond what developing or transitional countries would attempt. Yet, some have already been proven in the U.S. but have yet to be commercially replicated. Still others are already commercial worldwide. For these more-developed CCTs, a program to mitigate technical risks to developing and transitional countries could bring great benefits both to the U.S. and to those countries 
Chapter 4

\section{IMPLEMENTATION OF INTERNATIONAL CLEAN COAL TECHNOLOGY TRANSFER}

The U.S. Department of Energy (DOE), Office of Fossil Energy is currently working to implement the provisions of Section 1332 (Innovative Clean Coal Technology Transfer Program) of the Energy Policy of 1992 (Public Law 102-486, 42 U.S.C. 13362). DOE has developed an approach to implementation after extensive discussions and consultation with industry and other interested Federal agencies. This approach is based on the prudent mitigation of technical risks for selected CCT projects developed by U.S. firms. This Chapter describes how DOE is currently planning to implement Section 1332 and explains how industry input is being incorporated into that implementation.

\section{PLANNED APPROACH TO TECHNOLOGY TRANSFER}

Coal technology transfer activities will consist of three basic elements within the overall context of the Fossil Energy International Strategic Plan (see below). These elements are: (1) education and technical support, (2) "showcase" projects of advanced U.S. coal technologies, and (3) a fund for sharing the costs of project definition activities for commercial U.S. coal technologies. This approach is supported by U.S. industry and represents a prudent leveraging of U.S. government funds. A relatively small investment of $\$ 100$ million (less than 5 percent of the $\$ 2.5$ billion domestic CCT program) can result in several billion dollars per year of exports.

\section{Education and Technical Support}

The first element, education and technical support on CCTs, will be provided to U.S. industry and export credit agencies, multilateral banks and government and industry of potential market countries. U.S. Government review and objective analysis will inform the potential users and the financial institutions that serve them about the economics and technical performance of U.S. CCTs. Educational programs will also provide opportunities for U.S. industry to meet the decision makers in the foreign markets through trade missions and revenue trade missions. Clean coal trade missions have been well received by both potential foreign customers and U.S. industry and are seen by them as providing a cost-effective mechanism to acquaint the seller with the buyer. U.S. export credit agencies are increasing support for power and environmental projects in developing countries and are in need of the technical support of the staff of the Clean Coal Program. The Clean Coal Office is providing technical support to the Trade Development Agency, Export-Import Bank, Agency for International Development and the World Bank. 
"Showcase" Projects

Projects that "showcase" the cost-effectiveness of advanced U.S. clean coal technologies in developing and transitional countries will be developed in partnership with U.S. industry and host country stakeholders in key international markets. This would involve construction and operation of projects with U.S. advanced technologies and will confirm the confidence of the U.S. Government in these technologies. For the purpose of this program, "advanced technologies" are defined as those that have been proven through demonstration in the U.S., but have not yet achieved adequate commercial replication in the U.S. for the financial markets to accept them. This would include advanced power generation technologies for the removal of sulfur dioxide and nitrogen oxide. The U.S. Clean Coal Technology Demonstration Program, for example, is now producing tangible results for a number of technologies that can be replicated at home and abroad. Technologies to be replicated abroad would be those that the U.S. Government, U.S. industry and the host countries all agree have considerable future replication potential in those countries. Due to the novel aspects of utilizing the advanced technology in the host country and the associated performance risk, however, the commercial means of financing may not be readily available for these projects.

Two markets stand out as prime candidates for early showcase projects: China and Central Europe. China is emerging as a large market for environmentally-acceptable, high-efficiency power generation technology. It needs to increase its power generation capacity by $200 \mathrm{GW}$ over the next fifteen years. ${ }^{1}$ This contrasts with about $\mathbf{4 0} \mathrm{GW}$ anticipated for the U.S. during the same period. Coal will be the primary fuel for these facilities, and the Chinese government has identified Integrated Gasification Combined Cycle as its preferred technology for power generation. In addition, the Chinese government has stated that its own industry does not have the capability to construct all this capacity and that they intend to import much of this equipment. The Chinese have stated that they prefer U.S. equipment, but competition is strong. The Chinese have the ability to raise the necessary capital. Central Europe, in contrast, already has major environmental problems from uncontrolled coal utilization. This region represents a large market $(170 \mathrm{GW})$ for technologies to upgrade the environmental performance of existing coal-fired facilities. A project in each of these markets would accelerate the acceptance of U.S. technology and provide a competitive edge for U.S. equipment and services. Chapter 2 briefly profiles both of these markets.

The Department has requested funding in the FY 1995 to initiate showcase clean coal technology projects in China and Central Europe aimed at reducing the risk of building proven advanced technologies in countries with little previous experience using the technology. The new $\$ 75$ million initiative calls for

'Tan Aixing, Ministry of Electric Power, "A Review of Development in Key Markets, the People's Republic of China," Conference on Private Power in China, San Francisco, February 7-8, 1994. 
DOE to provide financial assistance of 10 to 25 percent of project capital costs. Well in excess of this amount would be returned to the U.S. market through equipment sales to the showcase projects.

DOE's financial assistance of $10-25$ percent of the capital requirements is intended to reduce the risks of building a new technology. The cost share could be structured to achieve an acceptable rate of return to the developer of the project. This will enable the selection of "showcase" technologies for evaluation by potential foreign and U.S. users. This approach for marketing advanced technologies to developing and transitional countries provides a source of financing not obtainable through the commercial markets, allocates risk among multiple funding sources and expedites project development through a single government agency. Most importantly, it develops a foundation for market acceptance of U.S. technologies by demonstrating confidence in and commitment to those technologies and markets. More is involved in marketing advanced technologies in foreign markets than just offering "the better mouse trap" and project financing; it is vital to demonstrate a willingness to invest in the future of your customer.

\section{Cost Sharing of Definitional Studies for Commercial Technology}

As discussed in Chapter 3, a series of preliminary activities is undertaken by U.S. project developers before they commit to undertake a project. Some of these are financed through programs at the various U.S. export finance agencies. Primarily, these are prefeasibility and feasibility studies. None is available for feasibility studies in China. Support for the later and more expensive project definition activities is more limited and on less favorable terms. Such definitional activities are required before commercial project financing for the entire project can be obtained.

Lack of support for definitional activities presents a hurdle for many projects, especially those involving state-of-the-art (but still commercial) technology that is inherently more technically uncertain. On average, it costs five times more to develop a project overseas. Many of the U.S. firms that market clean coal technologies do not have the capital to invest in the development of overseas marketing and project development. With the increased use of project financing, more front-end definition and development costs are required, which is costly even for well capitalized organizations.

DOE's program could provide cost-sharing of project definitional activities for technology that is commercial in the U.S., but not in the host country. Funds for these activities would be more readily available through DOE-sponsored project definition activities so that the project could then obtain financing through the Export-Import Bank, OPIC, World Bank or commercial sources. The activities to be cost-shared could include sufficient engineering and design to support an adequate cost estimate for financing, developing supply and sales agreements, and defining risks and approaches to mitigate risks. This program would encourage the export of commercially available U.S. equipment for meeting the current and near term needs of the eligible nations (as defined in Section 1332). Focusing on state-or-the- 
art commercial U.S. technologies would have the most immediate impact on reducing the U.S. trade deficit and creating highly-skilled U.S. jobs.

DOE will work with the Trade and Development Agency (TDA) to develop this program. In addition, the program will be structured to comply with all Organization of Economic Cooperation and Development (OECD) requirements.

\section{Interagency Cooperation}

In developing the proposed program, DOE consulted with the Treasury Department, the Export-Import Bank, the Overseas Private Investment Corporation (OPIC), TDA and the Agency for International Development (A.I.D.). These discussions covered the most appropriate means of financing projects under the Transfer Programs and the Organization for Economic Cooperative Development (OECD) rules for export credits. As a result of these consultations, DOE became convinced that the most efficient, economical and prudent approach to implementing a transfer program for commercial technologies should involve organizations already experienced in financing foreign investments. DOE is investigating how to organize a program working with these export financing agencies coordinated by the Trade Promotion Coordinating Committee.

DOE would provide funds for conceptual designs and definition for projects utilizing eligible technologies. The DOE funds would be cost-shared up to fifty percent with U.S. industry. DOE could serve as the focal point and lead coordinator among the federal agencies to ensure a smooth transition from the definition phase to the ultimate financing organization. Prior to initiating a study it would be determined that: (1) the project represents a development priority for the host country, (2) financing for the project is likely if the study results are attractive and (3) the potential for U.S. exports for subsequent projects is significant. Based on the results of these studies, the industrial participant could elect to seek financing from other agencies or any other source. Projects with sufficient definition could proceed directly to the Export-Import Bank for financing. DOE would provide the Export-Import Bank with the technical experts for evaluating investments and would participate in the monitoring of the technical progress during project implementation.

In the international market, the financing flexibility and terms may be more important for equipment sales and services than the merits of the technology being offered. To achieve the objectives of the Technology Transfer Program defined by the Energy Policy Act, there is considerable merit to implementing the program through a marriage of DOE technical expertise with the financial and business expertise of the agencies that finance overseas projects. By structuring the program as described, industry would continue to work with the same organizations as it has in the past for seeking overseas financing. 


\section{Auplicable Projects and Technologies}

As required by Section 1332 of EPACT, the program will be applicable to projects in a host developing or transitional country where a U.S. firm has an equity interest in a project. This program could include grassroots, retrofit or repowering projects. Where appropriate, government financing could be packaged for the entire project, for the incremental cost for the portion of the project applicable to energy efficiency or environmental controls, or just for the differential cost of using U.S. technology rather than the conventional technology generic to the host country.

Under Section 1332 of EPACT the project should use U.S. clean coal technology, and where appropriate U.S. coal resources, in meeting the applicable energy and environmental requirements of the host country. For the advanced technology projects it will be important to select candidate technologies that have a good potential to achieve economic success in subsequent projects in the host country or region. Assistance would be structured to reduce the incremental cost of the technologies over the cost of what has been conventional practice in these countries. Technologies would be selected for which the cost differential would disappear with the learning experience of the demonstration project. U.S. government financial assistance would be used to reduce the private capital investment in the demonstration project to achieve an acceptable rate of return and could be leveraged to raise debt in the capital markets.

\section{Fossil Energy International Activities}

Fossil energy international activities support the United States Department of Energy and Office of Fossil Energy objectives to improve the United States economy and enhance U.S. competitiveness and technological advantage; improve the global environment; more effectively manage U.S. energy resources; and increase U.S. and global energy security. The activities encourage the use of U.S. technologies, energy resources and services abroad, thus expanding markets for U.S. firms.

The objective of fossil energy international activities is to help lower barriers relevant to fossil energy products, services and resources. These activities help U.S. industry sell those products, services and resources that advance DOE's objectives in foreign markets in a way that brings mutual benefit to the U.S. and its foreign partners. These markets include power generation, industrial and pollution control applications for fossil fuel utilization, and the exploration, production, beneficiation, refining and transportation of coal, oil and natural gas. The products, services and resources advanced in these markets include:

- Products (equipment, components and intellectual property);

- Services (project development and operation, architect, engineering and construction, consulting services of various types and financial services); and

- Resources (coal production and preparation, natural gas, crude oil and products) 


\section{INCORPORATION OF INDUSTRY COMMENTS}

For over two years, DOE has engaged in an extensive dialogue with industry that has led to the shaping of this program. The dialogue has included extensive ongoing discussions with CCT project developers, equipment manufacturers and supporting industries including the financial community. These discussions led to both the Fossil Energy International Program and to the development of the draft plan for International Clean Coal Technology Transfer. This draft plan was reviewed in detail with nearly two hundred industry representatives at a public meeting held in Washington D.C. on February 10 and 11, 1994. The suggestions and comments received in these two forums have greatly shaped DOE's plans for implementation of the coal technology transfer program.

\section{Industry Discussions}

Throughout 1992 and 1993, a series of meetings were held between Office of Fossil Energy Staff and representatives of relevant industry groups to discuss the U.S. industry needs for support in the international CCT marketplace. The comments received in these meetings helped shape both the Fossil Energy International Program generally and the International Clean Coal Technology Transfer Initiative spucifically. These meetings highlighted several important considerations:

- U.S. industry has a strong interest in international CCT projects.

- Financing issues are critical to project development.

- Technology offerings of U.S. industry must match the real needs of customers.

- Aggressive export assistance by their governments gives foreign competitors a financial and promotional edge.

- Institutional barriers to the development of large-scale projects are high in developing and transitional countries.

- Advanced technologies will not be built until technological risks are mitigated.

\section{Public Meeting}

A public meeting was held in Washington, D.C. on February 10 and 11 to solicit comments by U.S. industry on DOE's proposed approach to the International Clean Coal Technology Transfer Program. This meeting was announced in the Federal Register, through a press release, and through a mailing to companies and organizations known to be interested in clean coal technologies. The two-day agenda included presentations by the DOE on the planned scope and approach for the International Clean Coal Technology Transfer and by other Federal Agencies (EximBank, TDA, OPIC and EPA) involved in the financing of related U.S. exports. Three breakout sessions were held on regional markets with representatives from the embassies of countries in those markets: Asia-Pacific, Central Europe and the 
Newly Independent States, and Africa/Americas. The entire second day was devoted to discussing impediments to the financing of international clean coal projects under Section 1332 and to identifying financial mechanisms to assist U.S. industry participation in the international marketplace. Representatives of U.S. project developers also gave presentations on the difficulties they faced developing projects.

The meeting was attended by approximetely 250 representatives of U.S. industry and trade groups. These included representatives of equipment manufacturers, project developers, architect-engineering firms, constructors, utilities, trade associations and a variety of service providers. Throughout the meeting, in both plenary and breakout sessions, comments and suggestions were solicited from the industry representatives on the proposed International Clean Coal Technology Transfer Program. In particular, the audience was provided with the following list of questions and discussion points before the meeting:

1. Problems of doing business in developing countries

2. What would be the most useful role of the government?

3. Views on the "straw man" approach towards meeting the needs of industry

4. Apropriate forms of finance or risk mitigation

5. A few "showcase" projects vs. maximum projects through EximBank funding

6. Solicitation structure

7. Definition of U. S. firm and U. S. clean coal technology

8. Countries with the best prospects of success for initially conducting the program

9. Other topics of interest

\section{Industry Comments}

A wide range of comments and suggestions were received on the proposed program and on the opportunities and difficulties of developing projects in foreign countries. These included not only suggestions related to the proposed Innovative Clean Coal Technology Transfer Program, but also ideas for helping countries create viable institutional and economic infrastructures to support large, commercially-financed projects.

General Comments. Financing is seen as the key to the development of U.S. projects in foreign countries. In addition, a variety of institutional factors were seen as barriers to financing relative to utility and environmental regulation and the legal and contractual basis for project development. Inflation, devaluation and convertibility risks are also seen as problems in many developing and transitional countries. Industry representatives suggested that the U.S. Government can help countries structure markets for power projects and assist U.S. firms in several ways:

\footnotetext{
Providing Assistance to Project Developers

Expressing support for environmental technologies and their transfer, Expressing confidence in U.S. CCTs, Setting precedents that can be replicated, Having local embassies help with local contacts,
} 


\section{Helping Structure Financial Terms}

- Urging host governments to facilitate necessary commercial contracts and guarantees,

- Assisting in structuring longer-time financing consistent with the needs of the parties,

- Working with countries to create mutually-understood "rules of the game,"

- Helping transitional countries develop standard offer contracts,

\section{Helping Countries Develop Viable Institutions}

- Working with developing and transitional countries to develop local capital markets,

- Helping host-country environmental agencies set understandable environmental standards,

- Defining and enforcing intellectual property rights.

Asia Pacific Region. Great opportunities were seen throughout the Asia Pacific Region. The large needs of China and India for CCTs were specifically highlighted by the industry representatives. These representatives made several other points:

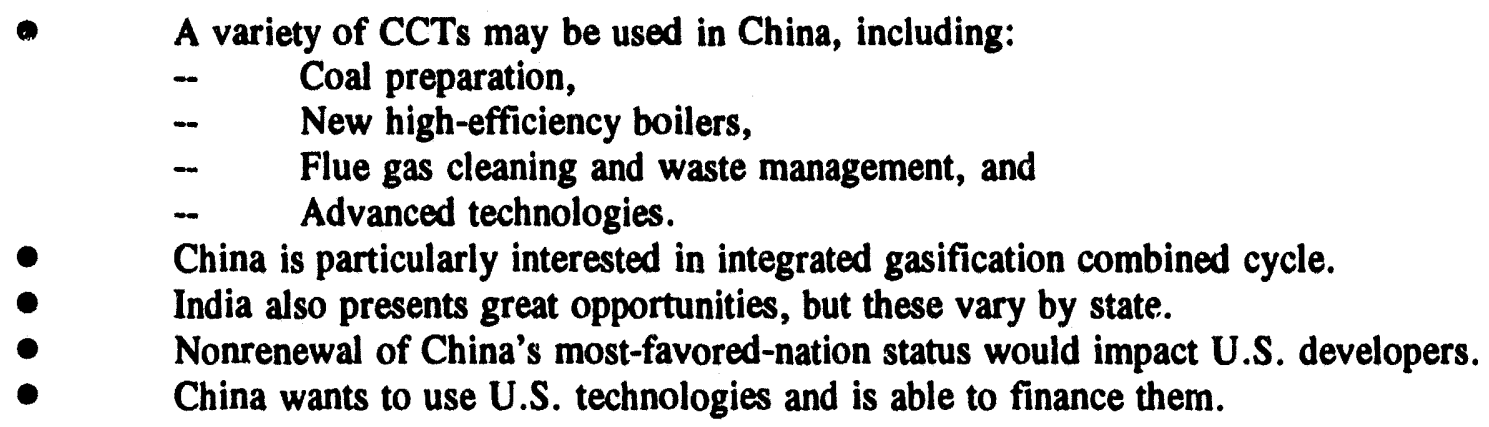

Central Europe and the Newly Independent States. Project finance is particularly difficult in Central Europe due to significant legal and commercial barriers:

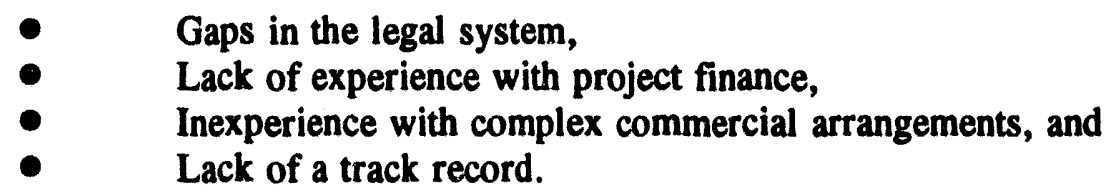

The greatest needs for technology are seen as those for retrofit of efficient and clean technologies for existing coal power plants. Low electricity prices in many Central European countries preclude adequate revenue to cover project costs.

Central Europeans, while technically astute, are perceived by U.S. companies as often not understanding how business works in a "free market." They have many misconceptions that make it difficult to negotiate with them. For example, they cannot understand why developers would need a 25-30 percent return to account for the large risk. A major problem is that many managers do not know what to do now that "free money" is no longer available from the central government. A U.S. government program was suggested for American business school teachers to show top officials in transitional countries how western capital markets work. 
Africa/Americas. Little information regarding market potential and the business opportunities in South America and Africa is currently available. Several recommendations were made:

- DOE should conduct a comprehensive effort to define the opportunities for U.S. business, as has been done for the other regions.

DOE should develop a more holistic approach to South America and Africa that would include promotion of U.S. power generation technologies, personnel training, institutional development and other technical assistance projects. This type of engagement will demonstrate a commitment from the U.S. and give U.S. business a better chance at obtaining contracts in these countries.

DOE, A.I.D. and other U.S. Government agencies could work with organizations such as the Inter-American Development Bank, the African Development Bank, the World Bank and the Southern African Development Community (SADC) to develop power sector programs in South American and African countries with the most potential.

- DOE should adopt a broad approach for Africa and South America that includes all fossil fuels (coal, oil, gas) and renewable energy.

In Africa, a regional approach may be more appropriate because many of the individual country markets are too small to be significant on their own, but within the regional context, they may provide good opportunities. Many African countries are members of regional economic organization such as the SADC.

South America and Africa should be included in DOE and other U.S. Government programs such as the Joint Implementation Program.

Proposed International Technology Export Structure. Numerous comments were received on the structure of the proposed International Clean Coal Technology Transfer Program:

Integrated Gasification Combined Cycle is seen as a prime technology for many markets. At the present time, however, it presents a technical risk that might preclude it from consideration in these markets. Government help is necessary to mitigate this risk.

Feasibility studies and project development should be financed by "recycling funds" repaid by successful projects. If a project goes forward, money would be returned to the funding source; if the project does not proceed, no repayment would be needed.

- Restrictions on U.S. content should not skew the economics of the project. Equipment should be procured where the economics are best and quality control requirements are met. The least number of initial constraints will benefit the process developers; they will be better able to define project content that gives best cost.

DOE should be directly involved in the process of selecting projects. DOE's knowledge of the process of acquiring advanced technologies will help to allay concerns of developing countries. Credibility plus dollars is key to success. A quick approval process for project selection is key. 
- Showcase projects can help to justify tighter environmental laws in developing countries and economies in transition. International Clean Coal Technology projects will encourage enforcement of environmental regulations and thus expand markets.

\section{Method of Incurporation}

Most of the industry comments received during the public meeting are being addressed by either the planned international technology transfer initiative or by the Office of Fossil Energy International Program generally. As already noted, comments and suggestions from earlier meetings have already been incorporated into the design of both the technology transfer initiative and Fossil Energy International Program.

Many of the comments at the public meeting related to opportunities in specific markets or to the need to overcome financial and institutional barriers in developing and transitional countries. To a large extent, the comments received on these topics confirmed the industry input already received and the results of DOE's prior work in this area. DOE has already performed market assersments that have identified the major markets and has structured its activities to focus on them. In addition, the major thrust of the Fossil Energy International Program is on overcoming financial and institutional barriers. To the extent that other Federal agencies are central to addressing these issues, DOE will be cooperating with those agencies through the TPCC.

The comments on one market-Africa-were relatively new. A number of industry representatives pointed out what they believed to be significant opportunities on that continent and expressed concerns that it not be left out of Fossil Energy Planning.

Considerable positive interest was expressed in the International Clean Coal Technology Transfer Activities. No major objections were made to the basic concepts or structures. A number of detailed suggestions (enumerated above) were made and these are currently under review. Where appropriate, they will be incorporated into the program should funding be appropriated in FY 1995. 

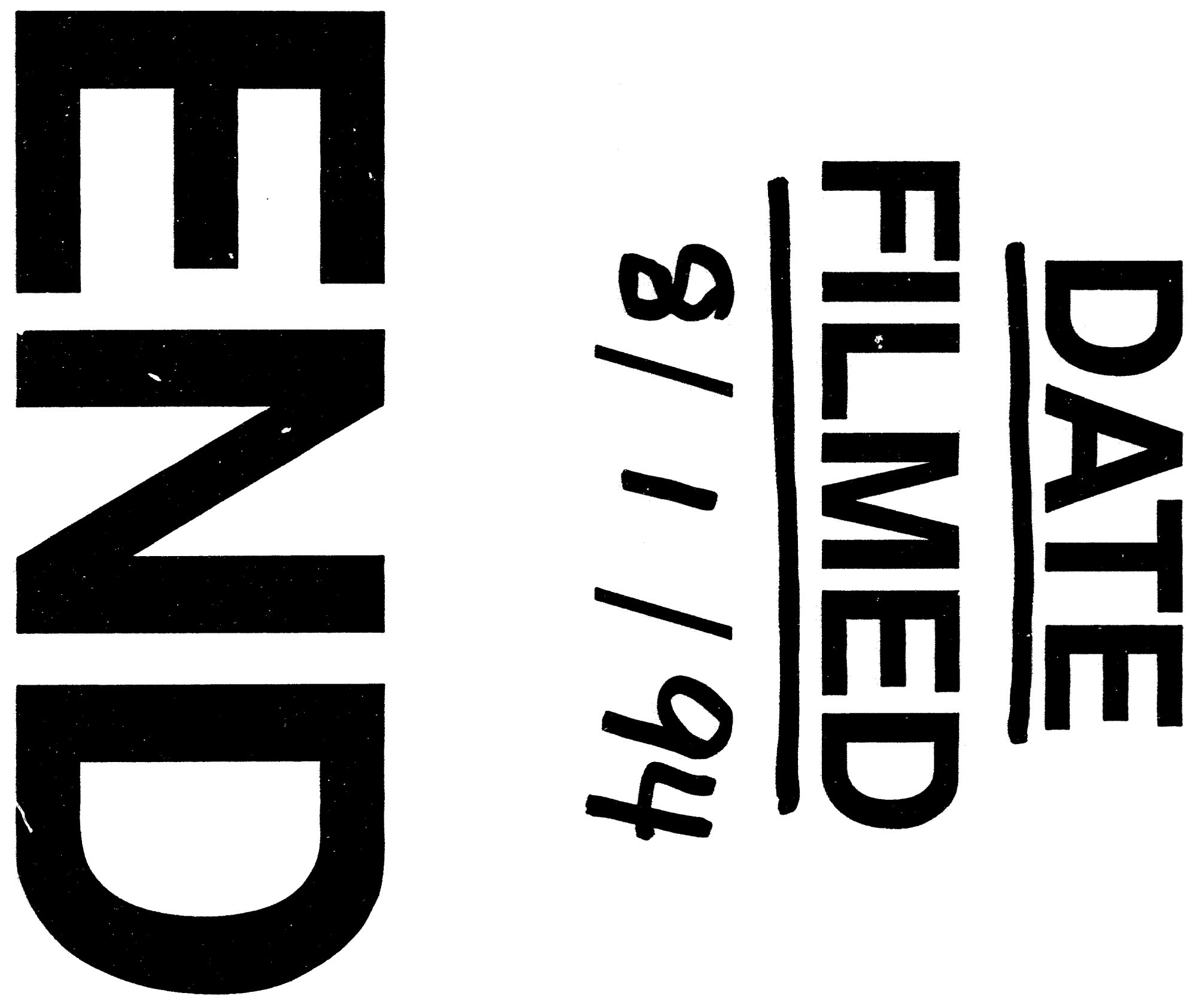
